\title{
Influence of Fermentation of Pasteurised Papaya Puree with Different Lactic Acid Bacterial Strains on Quality and Bioaccessibility of Phenolic Compounds during In Vitro Digestion
}

\author{
Florence M. Mashitoa ${ }^{1}$, Stephen A. Akinola ${ }^{2} \mathbb{D}$, Vimbainashe E. Manhevi ${ }^{2} \mathbb{D}$, Cyrielle Garcia ${ }^{3}(\mathbb{D}$, \\ Fabienne Remize ${ }^{3}$ (D) Retha. M. Slabbert $^{1}$ and Dharini Sivakumar ${ }^{2, *(D)}$ \\ 1 Department of Horticulture, Tshwane University of Technology, Pretoria West 0001, South Africa; \\ mashitoakganase@gmail.com (F.M.M.); slabbertmm@tut.ac.za (R.M.S.) \\ 2 Phytochemical Food Network Group, Department of Crop Sciences, Pretoria West 0001, South Africa; \\ akinolastephen3@gmail.com (S.A.A.); manhivive@tut.ac.za (V.E.M.) \\ 3 Qualisud, Univ Montpellier, Univ de La Réunion, CIRAD, Institut Agro, Avignon Université, \\ F-34398 Montpellier, France; cyrielle.garcia@univ-reunion.fr (C.G.); fabienne.remize@univ-reunion.fr (F.R.) \\ * Correspondence: SivakumarD@tut.ac.za
}

Citation: Mashitoa, F.M.; Akinola, S.A.; Manhevi, V.E.; Garcia, C.; Remize, F.; Slabbert, R.M.; Sivakumar D. Influence of Fermentation of Pasteurised Papaya Puree with Different Lactic Acid Bacterial Strains on Quality and Bioaccessibility of Phenolic Compounds during In Vitro Digestion. Foods 2021, 10, 962. https://doi.org/10.3390/foods10050962

Academic Editors: Adam Wasko and Waldemar Gustaw

Received: 29 March 2021

Accepted: 25 April 2021

Published: 28 April 2021

Publisher's Note: MDPI stays neutral with regard to jurisdictional claims in published maps and institutional affiliations.

Copyright: (c) 2021 by the authors. Licensee MDPI, Basel, Switzerland. This article is an open access article distributed under the terms and conditions of the Creative Commons Attribution (CC BY) license (https:// creativecommons.org/licenses/by/ $4.0 /)$.

\begin{abstract}
This study describes the impact of utilising different strains of lactic acid bacteria (LAB) for the fermentation of papaya puree and their effect on the quality parameters and bioaccessibility of phenolic compounds during simulated in vitro gastrointestinal digestion. Papaya was processed into puree; pasteurised and fermented at $37^{\circ} \mathrm{C}$ for 2 days; and stored for 7 days at $4{ }^{\circ} \mathrm{C}$ using LAB strains Lactiplantibacillus plantarum $75\left(L 75^{*} D 2 ;\right.$ L75 $\left.^{*} \mathrm{D} 7\right)$, Weissella cibaria $64($ W64*D2; W64*D7) and Leuconostoc pseudomesenteroides $56\left(L 56^{*} D 2 ; L 56^{*} D 7\right)$, respectively. Non-fermented samples at 0 (PPD0), 2 (PPD2) and 7 days (PPD7) served as controls. $\mathrm{pH}$ was reduced with fermentation and was lowest in $L 56^{*} D 2(3.03)$ and $L 75^{*} D 2$ (3.16) after storage. The colour change $(\Delta E)$ increased with the fermentation and storage of purees; $L 75^{*} D 7$ showed the highest $\Delta E$ (13.8), and its sourness reduced with storage. The fermentation by $W 64^{*} D 7$ and $L 75^{*} D 7$ increased the \% recovery of chlorogenic, vanillic, syringic, ellagic, ferulic acids, catechin, epicatechin and quercetin in the intestinal fraction compared to the $L 56^{*} D 7$ and $P P D 7$. Fermentation by $W 64^{*} D 7$ and $L 75^{*} D 7$ significantly improved the antioxidant capacity of the dialysed fraction compared to the $L 56^{*} D 7$ or PPD7. $L 56^{*} D 7$-fermented papaya puree showed the highest inhibitory effect of $\alpha$-glucosidase activity followed by $L 75^{*} D 7$. $L 75^{*} D 7$ had a significantly higher survival rate. LAB fermentation affected the bioacessibilities of phenolics and was strain dependent. This study recommends the use of $L p b$. plantarum 75 for fermenting papaya puree.
\end{abstract}

Keywords: postharvest preservation; Lactobacillus; antioxidant activity; polyphenols; in vitro digestion

\section{Introduction}

Regular consumption of fruits and vegetables is important for a healthy lifestyle, and for the reduction in risk factors for non-communicable diseases [1]. Reports from the World Health Organization (WHO) and Food and Agriculture Organization (FAO) [2] of the United Nations in 2004 recommended an intake of $400 \mathrm{~g}$ of fruit and vegetable per day. However, the highly perishable nature of fruits and vegetables and lack of cold chain facilities, coupled with the energy cost requirements, limit their availability and shelf life. Therefore, fermentation technology guarantees the availability and safety of fruits and vegetables to the consumers during the off season [3]. Several researchers have reported an improvement in the antioxidants of fruits and vegetables during lactic acid fermentation $[4,5]$.

Carica papaya Linn., belonging to the family Caricaceae, known as pawpaw or papaya, is popularly produced and consumed in South America, Asia and Africa [6]. Papaya is a 
rich source of carotenes, vitamin $\mathrm{C}$, flavonoids, antioxidants, folate, potassium, magnesium and fibre [6]. LAB fermentation rapidly reduces the $\mathrm{pH}$, thus increasing acidity, which prevents the spoilage of fermented products [7]. Furthermore, fermentation enhances the antioxidant properties through the biotransformation of phenolic compounds by the metabolising LAB strains, resulting in the release of bioactive compounds [8]. However, the potential functionality of a compound depends on the amount that is available after gastrointestinal digestion compared to the original amount before digestion. The $\mathrm{pH}$ changes that occur during gastrointestinal digestion phases produce phenolic derivatives that are high in molecular weight, have low solubility and are unavailable for absorption, mainly due to oxidation or polymerisation reactions [9]. Shahid and Peng [10] stated that the interaction with protein, lipid, fibre and hydrolytic enzymes affects the bioaccessibility of phenolic compounds in the intestinal tract. In vitro digestion models are widely used by researchers to mimic digestion due to it cost effectiveness [9] and non-ethical clearance requirement. Pavan et al. [11] showed changes in total phenols and antioxidant activity during gastrointestinal digestion before and after the digestion of tropical fruits, such as araticum, papaya and jackfruit, and digestion decreased the levels of total phenols and antioxidant activity in papaya extracts. However, their finding did not show the influence of gastrointestinal digestion on predominant different phenolic components present in papaya juice. Therefore, we hypothesise that the fermentation with LAB increases the total phenol content, different phenolic metabolites and antioxidant capacity in fermented papaya puree after digestion at the dialysis phase, which is available for intestinal absorption.

The total phenolic content in papaya is reportedly $54 \mathrm{mg} \mathrm{GAE} / 100 \mathrm{~g}$ fresh weight (FW) [12]; however, the concentrations differ in various cultivars. Gayosso-García Sancho et al. [13] reported the ferulic acid content as $277.49-186.63 \mathrm{mg} / 100 \mathrm{~g}$ dry weight (DW), p-coumaric acid (229.59-135.64 mg/100 g DW) and caffeic acid (175.51-112.89 mg/100 g DW) contents in Maradol papaya from Mexico. Phenolic compounds inhibit $\alpha$-glucosidase and reduce glucose uptake in the small intestine, through the inhibition of disaccharide digestion [14]. A commercial fermented papaya preparation sold in Japan and the Philippines reportedly showed a significant decrease in plasma glucose levels in type 2 diabetic patients [15]. Therefore, this study was aimed to investigate the effect of LAB fermentation on the quality parameters, changes in major phenolic compounds, $\alpha$-glucosidase activity and to evaluate the influence of in vitro gastrointestinal digestion on phenolic components and antioxidant capacity of the pasteurised and fermented papaya puree.

\section{Materials and Methods}

\subsection{Chemicals}

Culture media were purchased from Biokar Diagnostics (Solabia group, Pantin, France) and Conda Laboratories (Madrid, Spain). Reagents were obtained from Sigma-Aldrich (Saint-Quentin Fallavier, France) and VWR chemicals (Fontenay-sous-Bois, France). Type VI-B porcine pancreatic $\alpha$-amylase, type I $\alpha$-glucosidase from baker's yeast, starch, $\mathrm{p}$ nitrophenyl- $\beta$-glucopyranoside (pNPG) and voglibase and other chemicals came from Sigma-Aldrich (Saint-Quentin Fallavier, France).

\subsection{Preparation of Fruit Purees}

The purchase of fruits was from the local growers in Réunion Island. Purees were prepared by peeling, cutting and blending the fruit pieces. The bottled fruit purees were then pasteurised in an agitating water bath at $80{ }^{\circ} \mathrm{C}$ for $15 \mathrm{~min}$ and cooled to room temperature $\left(28^{\circ} \mathrm{C}\right)$ for $2 \mathrm{~h}$ prior to fermentation.

\subsection{Reactivation of LAB Cultures and Fermentation of Fruit Purees}

Lactic acid bacteria used in the study were previously isolated from tomatoes (Lycopersicon esculantum), papaya (Carica papaya) and sliced cabbage (Brassica oleacera var. capitata) and genotyped and have been reported as safe [3]. The LAB strains Leuconostoc pseudome- 
senteroides 56, Weissella cibaria 64 and Lactiplantibacillus plantarum 75 were reactivated at $30{ }^{\circ} \mathrm{C}$ for $48 \mathrm{~h}$ in de Mann Rogosa Sharpe (MRS) broth (Biokar Diagnostics, Pantin, France). An aliquot of $100 \mu \mathrm{L}$ of each culture was transferred into new $9 \mathrm{~mL}$ MRS broth and then incubated for $48 \mathrm{~h}$ at $30^{\circ} \mathrm{C}$. Repeating the reactivation step twice was to achieve an active growing condition of the cultures, after which the culture cells were produced anaerobically in MRS broth incubated at $30{ }^{\circ} \mathrm{C}$ for $24 \mathrm{~h}$. The LAB cell pellet, obtained after centrifugation at $8000 \times g$ for $5 \mathrm{~min}$, was washed twice with sterile distilled water. The resulting LAB cells, re-suspended in $20 \mathrm{~mL}$ of sterile water, were used as stock of concentrated LAB cultures. The concentrations of the LAB cultures were determined using a spectrophotometric method via the optical density measurements in BMG LABTECH $\mathrm{GmbH}$, SpectroStar Nano, Ortenberg, Germany. A concentrated LAB cell was appropriately diluted to $0.05 \mathrm{McF}$ arland standard concentrations (6 Log CFU/mL) at $660 \mathrm{~nm}$. To $100 \mathrm{~g}$ of puree, $1 \mathrm{~mL}$ of the LAB culture $(6 \mathrm{Log} \mathrm{CFU} / \mathrm{mL})$ was inoculated and incubated at $37^{\circ} \mathrm{C}$ for 2 days; after this, it was stored for 7 days at $4{ }^{\circ} \mathrm{C}$. The non-fermented purees at $0(P P D 0)$ and 2 days (PPD2), and stored at $4{ }^{\circ} \mathrm{C}$ for 7 days (PPD7), were used as controls. Other treatments included papaya puree fermented with Leu. pseudomesenteroides 56 for 2 days $\left(L 56^{*} D 2\right)$ and stored at $4{ }^{\circ} \mathrm{C}$ for 7 days $\left(L 56^{*} D 7\right)$, papaya puree fermented with W. cibaria 64 for 2 days $\left(W 64^{*} D 2\right)$ and stored at $4^{\circ} \mathrm{C}$ for 7 days $\left(W 64^{*} D 7\right)$, and puree fermented with $L p b$. plantarum 75 for 2 days $\left(L 75^{*} D 2\right)$ and stored at $4{ }^{\circ} \mathrm{C}$ for 7 days $\left(L 75^{*} D 7\right)$. Fermented and non-fermented purees were stored at $-20^{\circ} \mathrm{C}$ prior to analysis, and the fermentation was performed in triplicate.

\subsection{Physicochemical Properties of Fermented and Non-Fermented Papaya Puree}

The physicochemical properties of only pasteurised and fermented papaya puree were determined at 0 and 2 days of fermentation, and 7 days of storage. The $\mathrm{pH}$ was measured using the EUTECH pH2700 Instruments (EUTECH Instruments, Illinois, IL, USA), while the total soluble solids (TSS) of samples was measured using the ATAGO PAL-3 pocket refractometer (Atago USA Inc., Tokyo, Japan). The obtained refractive index values were recorded in ${ }^{\circ}$ Brix. The total titratable acidity of samples was determined according to the method of Reddy et al. (2015). The effect of fermentation and storage on the colour of purees was determined using a CM-3500 d spectrophotometer that made use of spectraMagic NX software (Konica Minolta, Konica Minolta Sensing Inc, Tokyo, Japan). The degree of lightness $\left(L^{*}\right)$, red to green component $\left(a^{*}\right)$, and yellow to blue $\left(b^{*}\right)$ colour components of samples were measured. The calculation of the total colour difference $(\Delta E)$ was performed according to Managa et al. [16].

\subsection{Determination of Microbial Count and Survival of LABS}

The evaluation of the total viable count and surviving LAB count of the puree used pour plating techniques [17]; the plating of the serially diluted samples was on appropriate media. For the total fungal (yeast and mould) counts, the plating of the dilutions was on Yeast Extract Glucose Chloramphenicol Agar (YGCA), bacteria count on nutrient agar (NA) and surviving LAB count on MRS agar plates. The NA plates underwent incubation at $37^{\circ} \mathrm{C}$ for $24 \mathrm{~h}$, YGCA plates at $27^{\circ} \mathrm{C}$ for 5 days, while the incubation of the MRS plates was performed anaerobically at $30^{\circ} \mathrm{C}$ for $48 \mathrm{~h}$. The surviving LAB, aerobic bacterial and fungal counts were enumerated as logarithmic colony forming units per gram (Log CFU/g) of sample.

\subsection{Organoleptic Properties of Non-Fermented and Fermented Stored Papaya Purees}

The sensory evaluation of the puree used a quantitative descriptive analysis technique described by Oliveira et al. [18], with some modifications. The selection of nine trained panellists was from the pool of assessors trained to identify the desired characteristics of the puree. The panellists were composed of healthy male and female research employees. There were two training sections adopted, and the samples were rated using a structured scale ranging from 0 to 6 (absent $=0 ; 1-2.4=$ weak; $2.5-3.9=$ moderate; $-6=$ strong). The assessment of the perception of bright or dark orange colour was performed using ripe 
papaya juice $(100 \%)$ and papaya juice with $1 \%$ food grade browning as a reference, respectively. The characteristic aroma of papaya was assessed using a ripe papaya pulp juice $(100 \%)$, while the characteristics of a viscous food in the mouth (consistency) was assessed using ( $30 \%$ ) glucose syrup solution as a reference. The assessment of the perception of acid taste and fermented fruit (sourness) was performed by using a commercial unsweetened yoghurt, while the sweet taste characteristics on the tongue were evaluated using sucrose solution (70\%) as a reference. A commercial fresh fermented fruit concentrate was used as a reference to determine the overall acceptability. Coded samples were served chilled in white cups with lids to the panellists in a white light-illuminated cubicle. The means of the attributes were calculated, and the cut-off point was set at 2.5 for the acceptability of attributes.

\subsection{Determination of Total Phenolic Content}

Total phenolic content was determined according to Fessard et al. [3], using $30 \mu \mathrm{L}$ of 10-fold diluted sample and $150 \mu \mathrm{L}$ of Folin-Ciocalteu reagent, and afterwards adding $60 \mu \mathrm{L}$ of $700 \mathrm{mM} \mathrm{Na}_{2} \mathrm{CO}_{3}$ and holding in the dark for $1 \mathrm{~h}$. The absorbance at $760 \mathrm{~nm}$ was measured (Infinite M200 PRO, Tecan, Mannedorf, Switzerand) and results expressed in milligrams of gallic acid equivalent (GAE).

\subsection{Simulated In Vitro Gastrointestinal Digestion}

In vitro digestion, to test the bioaccessibility of antioxidant compounds, was carried out on ethanolic extract of fruit purees according to Brodkorb et al. [19], mimicking the gastric, intestinal and dialysis phases. A set of $10 \mathrm{~g}$ of fruit puree (fermented and nonfermented, stored for 7 days) was mixed with $16 \mathrm{~mL}$ of simulated gastric fluid (SGF). The mixture, held at $\mathrm{pH} 1.3$ by adjusting with $6 \mathrm{M} \mathrm{HCl}$, was incubated with freshly prepared pepsin solution $(10 \mathrm{~mL}$ solution in $0.1 \mathrm{M} \mathrm{HCl})$, sufficient to generate a $142 \mathrm{mg} / \mathrm{mL}$ sample. After $2 \mathrm{~h}$, simulated intestinal fluid (SIF) was added to the gastric solution and the $\mathrm{pH}$ maintained at 7.0 with $5 \mathrm{M} \mathrm{NaOH}$ before adding freshly prepared pancreatin-bile salt solution $\left(39.2 \mathrm{~mL}\right.$ of pancreatin $+6 \mathrm{~mL}$ of bile salts solution in $\left.1 \mathrm{M} \mathrm{NaHCO}_{3}\right)$ to produce a sample of $8.375 \mathrm{mg} / \mathrm{mL}$. The mixture was held for $2 \mathrm{~h}$ at $37^{\circ} \mathrm{C}$ with shaking at $100 \mathrm{rpm}$. The collection of the samples $(10 \mathrm{~mL})$ was carried out after the intestinal phase, with the remaining used for the dialysis phase. The sample remained at $-20^{\circ} \mathrm{C}$ to stop intestinal digestion. For dialysis, a dialysis bag $(10 \mathrm{~cm}$ max, mw cut-off $10 \mathrm{kda})$ was filled with $5.5 \mathrm{~mL}$ $\mathrm{NaCl}(0.9 \%)$ and $5.5 \mathrm{~mL} \mathrm{NaHCO}_{3}(0.5 \mathrm{M})$ placed in a beaker filled with SIF $(70 \mathrm{~mL})$ and incubated for $45 \mathrm{~min}$ at $37^{\circ} \mathrm{C}$, with shaking at $100 \mathrm{rpm}$. For analysis purposes, a $10 \mathrm{~mL}$ sample collected from the dialysis bag was lyophilised.

\subsection{Determination of FRAP Activity}

Total antioxidant scavenging activity was determined according to Managa et al. [16] using $0.2 \mathrm{~g}$ freeze-dried fruit puree extracted using $2 \mathrm{~mL}$ of sodium acetate buffer ( $\mathrm{pH}$ 3.6). An amount of $220 \mu \mathrm{L}$ of FRAP reagent solution was placed on a microplate $(10 \mathrm{mmol} / \mathrm{L}$ TPTZ (2,4,6-tris (2-pyridyl)-1,3,5-triazine) acidified with concentrated $\mathrm{HCl}$ and $20 \mathrm{mmol} / \mathrm{L}$ $\mathrm{FeCl}_{3}$ ), followed by $15 \mu \mathrm{L}$ of the homogenised puree extract. The absorbance measurement was performed at $593 \mathrm{~nm}$ (Spectrophotometer BMG LABTECH GmbH, SpectroStar Nano, Ortenberg, Germany). The reducing antioxidant power was expressed in Trolox $\mu \mathrm{mol}$ TEAC/100 g DW.

\subsection{Effect of Digestion on the Phenolic Profile of Fermented and Non-Fermented Papaya Purees}

Extraction and analysis of phenolics in fermented and non-fermented digested purees were performed according to the method of Palafox-Carlos et al. [20]. Digesta from fermented and non-fermented purees were freeze-dried $(0.25 \mathrm{~g})$ and homogenised into $10 \mathrm{~mL}$ of $80 \%$ methanol containing BHT $(1 \mathrm{~g} / \mathrm{L})$; then, $5 \mathrm{~mL}$ of $6 \mathrm{M}$ HCL was homogenised using a BV1000 vortex mixer (Benchmark Scientific Inc., Sayreville, NJ, USA) and the mixture stirred carefully. A 2510 model ultrasonic bath (Branson, LabFriend Pty Ltd., North Sydney, 
NSW, Australia) sonicated the mixture for $30 \mathrm{~min}$ at $70^{\circ} \mathrm{C}$, then centrifuged it at $10,000 \mathrm{rpm}$ for 15 min at $4{ }^{\circ} \mathrm{C}$ using a Hermle centrifuge (Model Hermle Z326k, Hermle Labortechnik $\mathrm{GmbH}$, Wehingen, Germany). The collected supernatants were filtered through a $0.22 \mu \mathrm{m}$ PTFE syringe filter (Grafiltech). The resulting filtrate was injected and analysed in the HPLC/UV-DAD system using a Shimadzu Prominence-i-LC-2030C 3D, Auto Sampler (SIL-20A) HPLC system (Shimadzu, Kyoto, Japan), coupled to a diode array detector for HPLC analysis. Chromatographic separation was achieved using a Shim-pack Gist C18 $5 \mu \mathrm{m}, 4.6 \times 250 \mathrm{~mm}$ reverse phase column with gradient elution at $30^{\circ} \mathrm{C}$, using a $10 \mu \mathrm{L}$ injection volume. The mobile phase consisted of $6 \%$ glacial acetic acid (solvent A) and $75 \%$ acetonitrile containing $5 \%$ glacial acetic acid (solvent $\mathrm{B}$ ). The elution gradient was $0-100 \%$ (B) for $30 \mathrm{~min}$, kept for $5 \mathrm{~min}$ at 100\% (B), then returned to $0 \%$ (B) for $3 \mathrm{~min}$ at a flow rate of $0.6 \mathrm{~mL} / \mathrm{min}$. The detection of analytes was performed at $280 \mathrm{~nm}$, and the compounds identified based on a combination of retention time and spectral matching based on standards.

\subsection{Determination of $\alpha$-Glucosidase Inhibition}

For the effect of fermentation on the antidiabetic activity of fermented and nonfermented purees, alpha-glucosidase assay was performed using samples obtained on day 7 [21]. Purees were homogenised with sodium phosphate buffer $(0.1 \mathrm{M})$ and dilutions $\frac{1}{2}$, $1 / 5,1 / 10$ and $1 / 20$ obtained. An aliquot of $62 \mu \mathrm{L}$ of sodium phosphate buffer, $50 \mu \mathrm{L}$ of enzyme and $62 \mu \mathrm{L}$ of inhibitor sample underwent mixing in a 96-well plate, and incubated for $2 \mathrm{~min}$ at $37^{\circ} \mathrm{C}$ under shaking. To the wells, $25 \mu \mathrm{L}$ of substrate solution was added and absorbance measured at $405 \mathrm{~nm}$ ((Infinite M200 PRO, Tecan, Mannedorf, Switzerand). The activity and percentage of enzyme inhibition in fruits extracts were determined using Equation (1) and Equation (2), respectively:

$$
\begin{gathered}
\text { OD test } t_{405}=\text { OD sample }- \text { OD negative control } \\
\% \text { Glucosidase inhibition }=100 \%-\text { activity of OD test }
\end{gathered}
$$

\subsection{Statistical Analysis}

This study used a completely randomised design with five replicates per treatment. The fermentation experiments were performed twice to ensure the reliability of data. Oneway analysis of variance (ANOVA) tested the significant differences between the means. Means were compared among the treatments by the least significant difference (LSD) test, at $p<0.05$, using the Genstat statistical programme for Windows 13th Edition, 2010 (VSN International Hempstead, Hertfordshire, UK).

\section{Results and Discussion}

\subsection{Physicochemical Properties of LAB-Fermented Papaya Purees}

Lactic acid bacteria have the ability to break down carbohydrates into organic acids [3], which could help in food preservation and enhance the safety of food. The $\mathrm{pH}$ of fermented and non-fermented papaya puree was in the range of 3.03 to 5.08 (Table 1). The $\mathrm{pH}$ values of purees reduced with fermentation after 2 days compared to the non-fermented sample (5.08). The highest reduction in the $\mathrm{pH}$ was obtained in $L 56^{*} D 2$ (3.03) and was not significantly different to $L 75^{*} D 2$ (3.16) fermented for 2 days, while the non-fermented at day zero had the highest $\mathrm{pH}$ (5.08). Moreover, after storage for 7 days, there was a significant increase in the $\mathrm{pH}$ of the fermented purees, except the control $(p \leq 0.05)$, relative to values at 2 days of fermentation. The increase in $\mathrm{pH}$ after 7 days of storage might have been caused by the poor survival of the LAB due to inappropriate conditions for growth during storage at $4{ }^{\circ} \mathrm{C}$, which could have enabled the growth and release of some yeast metabolites that could raise the $\mathrm{pH}$. The titratable acidity contents of purees ranged from 0.59 to $0.94 \mathrm{mg} / \mathrm{mL}$ lactic acid and increased with fermentation relative to the non-fermented sample. The titratable acidity was highest in $L 75^{*} D 2(0.94 \mathrm{mg} / \mathrm{mL})$ and lowest in the non-fermented puree $(0.59 \mathrm{mg} / \mathrm{mL})$ at day zero. The fermented samples were 
significantly different to the non-fermented samples $(p \leq 0.05)$, while the non-fermented samples at day 0 and 2 were not significantly different to each other $(p>0.05)$. The decrease in the $\mathrm{pH}$ with an increase in titratable acidity contents after 2 days of fermentation could be due to the activity of inoculated LABs in converting carbohydrate substrates in the purees into organic acid after two days of fermentation. Ayed et al. [22] reported a similar observation of $\mathrm{pH}$ decrease after fermentation in red grape juice.

Table 1. Changes in $\mathrm{pH}$ and total soluble solids ( ${ }^{\circ}$ Brix) of non-fermented and fermented papaya puree.

\begin{tabular}{|c|c|c|c|}
\hline Fruit Puree & $\mathrm{pH}$ & Titratable Acidity (mg/mL) & Total Soluble Solids $\left(\right.$ Brix $\left.^{\circ}\right)$ \\
\hline PPDO & $5.08 \pm 0.01^{\mathrm{a}}$ & $0.59 \pm 0.04{ }^{d}$ & $8.03 \pm 0.06^{a, b}$ \\
\hline PPD2 & $4.99 \pm 0.01^{\mathrm{a}, \mathrm{b}}$ & $0.63 \pm 0.02^{d}$ & $8.07 \pm 0.06^{\mathrm{a}, \mathrm{b}}$ \\
\hline PPD7 & $4.36 \pm 0.01^{\mathrm{b}}$ & $0.68 \pm 0.02^{c}$ & $8.50 \pm 0.02^{\mathrm{a}}$ \\
\hline$L 56^{*} D 2$ & $3.03 \pm 0.01 \mathrm{~d}$ & $0.76 \pm 0.02^{b}$ & $6.87 \pm 0.06^{\mathrm{d}}$ \\
\hline$L 56^{*} D 7$ & $3.88 \pm 0.01^{\mathrm{c}}$ & $0.73 \pm 0.02^{b}$ & $8.60 \pm 0.02^{\mathrm{a}}$ \\
\hline$W 64^{*} D 2$ & $3.76 \pm 0.01^{\mathrm{c}}$ & $0.80 \pm 0.02^{\mathrm{a}, \mathrm{b}}$ & $7.13 \pm 0.06^{\mathrm{c}}$ \\
\hline$W 64^{*} D 7$ & $4.09 \pm 0.01^{\mathrm{b}}$ & $0.71 \pm 0.02^{\mathrm{b}}$ & $7.80 \pm 0.17^{\mathrm{b}}$ \\
\hline$L 75^{*} D 2$ & $3.16 \pm 0.01^{\mathrm{d}}$ & $0.94 \pm 0.04^{\mathrm{a}}$ & $6.83 \pm 0.06^{\mathrm{d}}$ \\
\hline$L 75^{*} D 7$ & $3.36 \pm 0.01^{\mathrm{c}}$ & $0.84 \pm 0.04^{\mathrm{a}, \mathrm{b}}$ & $7.13 \pm 0.07^{c}$ \\
\hline
\end{tabular}

Values are mean \pm standard error of means; means followed by a different letter within the column are significantly different $(p \leq 0.05)$.

Key: $P P D 0=$ non-fermented papaya puree at 0 days; $P P D 2=$ non-fermented papaya puree at day 2; $L 56^{*} D 2$ = papaya puree fermented with Leu. pseudomesenteroides 56 for 2 days; $W 64^{*} D 2$ = papaya puree fermented with $W$. cibaria 64 for 2 days; $L 75^{*} D 2$ = papaya puree fermented with $L p b$. plantarum 75 for $2 \mathrm{~d} ; P P D 7=$ non-fermented papaya puree stored at $4{ }^{\circ} \mathrm{C}$ for $7 \mathrm{~d} ; L 56^{*} D 7=$ papaya puree fermented with Leu. pseudomesenteroides 56 stored at $4{ }^{\circ} \mathrm{C}$ for $7 \mathrm{~d} ; W 64^{*} D 7=$ papaya puree fermented with $W$. cibaria 64 stored at $4{ }^{\circ} \mathrm{C}$ for $7 \mathrm{~d} ; L 75^{\circ} D 7=$ papaya puree fermented with $L p b$. plantarum 75 and stored at $4{ }^{\circ} \mathrm{C}$ for $7 \mathrm{~d}$.

The titratable acidity contents of purees decreased slightly during storage for 7 days, thus signifying a decline in the fermentative activity of the inoculated LABs in the purees due to the possible death of some LAB cells during storage. The increase in $\mathrm{pH}$ during storage, as observed in the fermented purees, could be due to a decline in active LAB counts, which corroborates the decrease in puree acidity after storage. The reduced acidity could have enhanced the activities of some competing bacteria and fungi, which utilise organic acids as a carbon source, thereby producing metabolites that lower the $\mathrm{pH}$ of the purees [17]. Similar to the reduction in $\mathrm{pH}$ observed in this study, LAB fermented emmer -based beverages fortified with fruit juices have been reported to have lower $\mathrm{pH}$ after fermentation [23]. The higher degree of acidity characterised by low $\mathrm{pH}$, as observed in $L 75^{*} D 2$ at day 2 of fermentation and 7 days of storage, is suggestive of Lpb. plantarum being a strong hetero-fermenter that could survive at low $\mathrm{pH}$ and temperature.

The TSS content of the fermented and non-fermented purees ranged from 6.83 to $8.60{ }^{\circ}$ Brix (Table 1) and was highest in $L 56^{*} D 7$ and lowest in $L 75^{*} D 2$. The TSS content was significantly reduced after fermentation for 2 days compared to the non-fermented sample $(p \leq 0.05)$. However, $L 56^{*} D 2$ and $L 75^{*} D 2$ were not significantly different from each other, in line with the control at day 0 and $2(p>0.05)$. The reduction in the TSS contents of the fermented purees compared to the non-fermented purees could be due to the metabolic activities of inoculated LAB cultures that break down, reducing sugars into organic acid, confirmed by a reduction in the $\mathrm{pH}$ of the purees. The reduction in the TSS content after fermentation is in agreement with that obtained by Soibam et al. [24] in fermented sugarcane and beet juice. The TSS contents of purees increased during storage for 7 days. Samples $L 56^{*} D 7\left(8.60^{\circ}\right.$ Brix $)$ and non-fermented $\left(8.50^{\circ}\right.$ Brix $)$ puree were not significantly different $(p>0.05)$ from each other after 7 days of storage, in line with samples $L 75^{*} D 7$ and $W 64^{*} D 2\left(7.13^{\circ}\right.$ Brix). The increase in the TSS content during storage could be due to the hydrolysis of carbohydrates into reducing sugars, thus supporting the previous 
reports of an increase in the total soluble solid of stored kinnow juice [25] and carrot-orange juice [26].

\subsection{Effect of Fermentation and Storage on Colour Characteristics of Papaya Puree}

The effect of fermentation and storage on the colour characteristics of papaya puree is presented in Table 2. The luminosity of fermented and non-fermented puree ranged from 29.96 to 43.21 and was highest in the non-fermented puree prior to fermentation, and lowest in $L 75^{*} D 7$ papaya puree stored for 7 days. After fermentation and storage at cold temperature $\left(4^{\circ} \mathrm{C}\right)$, the luminosity $\left(L^{*}\right)$ of the puree reduced relative to the control. The purees fermented for 2 days were significantly different to the non-fermented purees at day $2(p \leq 0.05)$. The $L 56^{*} D 2$ and $W 64^{*} D 2$ were not significantly different $(p>0.05)$, while $L 75^{*} D 2$ significantly differed to others in terms of luminosity ( $\left.p \leq 0.05\right)$. The type of fermenting LAB cultures significantly influenced the colour parameters of the puree. Contrary to that obtained in other treatments, $W 64^{*} D 7$ had increased lightness upon storage for 7 days, thus suggesting the potential ability of W. cibaria 64 to inhibit enzymatic oxidation in samples.

Table 2. Colour characteristics of fermented and non-fermented papaya puree.

\begin{tabular}{ccccc}
\hline Fruit Puree & $\boldsymbol{L}^{*}$ & $\boldsymbol{a}^{*}$ & $\boldsymbol{b}^{*}$ & $\Delta \boldsymbol{E}$ \\
\hline PPD0 & $43.21 \pm 0.01^{\mathrm{a}}$ & $23.15 \pm 0.01^{\mathrm{c}}$ & $52.76 \pm 0.01^{\mathrm{b}, \mathrm{c}}$ & \\
$P P D 2$ & $35.07 \pm 0.06^{\mathrm{b}}$ & $24.48 \pm 0.01^{\mathrm{b}}$ & $58.02 \pm 0.01^{\mathrm{a}}$ & $9.8 \pm 0.5^{\mathrm{g}}$ \\
PPD7 & $32.43 \pm 0.01^{\mathrm{d}}$ & $25.62 \pm 0.01^{\mathrm{a}, \mathrm{b}}$ & $54.42 \pm 0.01^{\mathrm{b}}$ & $11.2 \pm 1.0^{\mathrm{d}}$ \\
$L 56^{*} \mathrm{D} 2$ & $33.91 \pm 0.08^{\mathrm{c}}$ & $23.87 \pm 0.03^{\mathrm{c}}$ & $52.33 \pm 0.01^{\mathrm{c}}$ & $9.3 \pm 0.1^{\mathrm{h}}$ \\
$L 56^{*} D 7$ & $32.13 \pm 0.01^{\mathrm{d}}$ & $25.33 \pm 0.01^{\mathrm{a}, \mathrm{b}}$ & $53.86 \pm 0.01^{\mathrm{b}}$ & $11.3 \pm 1.0^{\mathrm{c}}$ \\
$W 64^{*} D 2$ & $32.99 \pm 0.02^{\mathrm{c}}$ & $24.97 \pm 0.02^{\mathrm{b}}$ & $53.13 \pm 0.15^{\mathrm{b}, \mathrm{c}}$ & $10.4 \pm 0.1^{\mathrm{e}}$ \\
$W_{64} \mathrm{D} 7$ & $33.65 \pm 0.01^{\mathrm{c}}$ & $24.35 \pm 0.02^{\mathrm{b}}$ & $55.72 \pm 0.01^{\mathrm{a}, \mathrm{b}}$ & $10.1 \pm 0.7^{\mathrm{f}}$ \\
$L^{\mathrm{b}} 5^{*} D 2$ & $31.29 \pm 0.01^{\mathrm{d}, \mathrm{e}}$ & $24.97 \pm 0.02^{\mathrm{b}}$ & $50.62 \pm 0.01^{\mathrm{d}}$ & $12.3 \pm 2.3^{\mathrm{b}}$ \\
$L 75^{*} D 7$ & $29.96 \pm 0.05^{\mathrm{e}}$ & $26.38 \pm 0.02^{\mathrm{a}}$ & $50.61 \pm 0.01^{\mathrm{d}}$ & $13.8 \pm 0.4^{\mathrm{a}}$ \\
\hline
\end{tabular}

Values are mean \pm standard error of means; means followed by a different letter within the column are significantly different $(p \leq 0.05)$. $L^{*}=$ degree of lightness; $\mathrm{a}^{*}=$ red to green component; $\mathrm{b}^{*}=$ yellow to blue; $\Delta E=$ total colour difference.

The redness to greenness characteristics $\left(a^{*}\right)$ of the puree ranged from 23.15 to 26.38 . The degree of redness to greenness of the puree did not significantly increase with fermentation and storage and was highest in $L 75^{*} D 7$ (26.38). However, $a^{*}$ in $L 56^{*} D 2$ and $W 64^{*} D 7$ increased after fermentation and storage for 7 days, respectively, while $L 56^{*} D 2$ was not significantly different to the control before fermentation $(p>0.05)$. The yellow to blue components of the puree was in the range 50.61-58.02 and was highest in the non-fermented sample. At day 2 of fermentation, the $b^{*}$ component of fermented samples was significantly different to the control, except $W 64^{*} D 2$, while upon storage, samples were not significantly different to the control, except $L 75^{*} D 7$. The decreased luminosity of the puree and high colour change in stored fermented papaya puree could be due to an enzymatic oxidation caused by the reduced fermentation and acidity in the puree during storage. The $b^{*}$ colour coordinate related to the yellow colour of the puree used for the calculation of $\Delta E$ relates to the colour change.

The $\Delta E$ relates to the colour change, and is associated with the rate of enzymatic browning in fruit juices and purees [26]. The $\Delta E$ of the samples ranged from 9.8 to 13.8. The colour change in the puree was lowest in $L 56^{*} D 2$ and highest in $L 75^{*} D 7$. The $\Delta E$ significantly increased by fermentation and storage $(p \leq 0.05)$; therefore, fermenting with different types of LAB strains and storage at a cold temperature influenced the $\Delta E$ in papaya puree. There was a significant colour change in papaya puree, as its $\Delta E$ values were greater than two. The colour change in fruit and juices correlate with the enzymatic activities of polyphenolic oxidase [27]. Hence, the high $\Delta E$ values in stored fermented purees could be due to an auto-oxidation of polyphenolic compounds [28].

Key: $P P D 0=$ non-fermented papaya puree at 0 days; $P P D 2=$ non-fermented papaya puree at $2 \mathrm{~d} ; L 56^{*} D 2$ = papaya puree fermented with Leu. pseudomesenteroides 56 for $2 \mathrm{~d}$; 
$W 64^{*} D 2$ = papaya puree fermented with $W$. cibaria 64 for $2 \mathrm{~d} ; L 75^{*} D 2=$ papaya puree fermented with $L p b$. plantarum 75 for $2 \mathrm{~d}$; PPD7 = non-fermented papaya puree stored at $4{ }^{\circ} \mathrm{C}$ for $7 \mathrm{~d}$; $L 56^{*} \mathrm{D} 7$ = papaya puree fermented with Leu. pseudomesenteroides 56 stored at $4^{\circ} \mathrm{C}$ for $7 \mathrm{~d}$; $W 64^{*} \mathrm{D} 7$ = papaya puree fermented with $W$.cibaria 64 stored at $4{ }^{\circ} \mathrm{C}$ for $7 \mathrm{~d}$; $L 75^{*} \mathrm{D} 7=$ papaya puree fermented with $L p b$. plantarum 75 and stored at $4{ }^{\circ} \mathrm{C}$ for $7 \mathrm{~d}$.

\subsection{Survival of LABs in Papaya Purees after Fermentation and Storage}

The surviving LAB counts in fermented and non-fermented purees ranged from 0.92 to 9.25 Log CFU/g in puree (Figure 1). As expected, there was a significant increase in the LAB count of purees fermented for 2 days, while upon storage for 7 days, there was a significant decrease, except in $L 75^{*} D 7$, which was more stable after storage $(p \leq 0.05)$. Samples $L 75^{*} D 2$ (9.25 Log CFU/g) and $L 75^{*} D 7$ (9.24 Log CFU/g) were significantly higher than other fermented and non-fermented samples and were not significantly different from one another $(p \leq 0.05)$. This suggests the stability and survival of Lpb. plantarum-fermented papaya purees at acidic condition after storage for 7 days. Lpb. plantarum prefers glucose and lactose as a carbon source and can easily adapt to different conditions [29], which accounts for its versatile use in fermentation. The stability of $L 75^{*} D 7$ puree suggests its potential to be used as functional food (probiotics) that can help to manage dysbiosis in the gastrointestinal tract. $L p b$. plantarum produces antimicrobial compounds, such as plantaricin, which can inhibit the growth of spoilage and pathogenic microorganisms [30]. At day 2 of fermentation, fermented purees were significantly different from others and the non-fermented samples; however, after storage, $W 64^{*} D 2$ was not significantly different to $L 56^{*} D 7$. The surviving LAB counts significantly decreased after storage, except in $L 75^{*} D 7$; this might be associated with the inactivation or death of some LAB cultures due to unfavourable growing conditions during storage. The survival of Lpb. plantarum in the puree after storage supports the finding of Srisukchayakul et al. [31] on the acid tolerance of $L p b$. plantarum in fruit juices stored in refrigerated conditions. The highest LAB count decrease in fermented purees was in $W 64^{*} D 7$. Thus, W. cibaria 64 culture might not be able to survive cold storage $\left(4^{\circ} \mathrm{C}\right)$ for 7 days unlike the $L p b$. plantarum-fermented papaya puree. The variation in the LAB cell survival of fermented mango puree after storage could be due to the unique characteristics of individual LAB cultures used in the study. The fungal counts (1-3 Log CFU/g) and total viable bacteria (data not shown) were within the acceptable limits for fruit juices [32].

Values are the mean \pm standard deviation, and means followed by a different letter within the row are significantly different $(p \leq 0.05)$. Key: PPD0: non-fermented papaya puree at 0 days; PPD2: non-fermented papaya puree at day $2 ; L 56^{*} D 2$ : papaya puree fermented with Leu. pseudomesenteroides 56 for 2 days; $W 64^{*} D 2$ : papaya puree fermented with $W$. cibaria 64 for 2 days; $L 75^{*} D$ : papaya puree fermented with $L p b$. plantarum 75 for 2 days; PPD7: non-fermented papaya puree stored at $4{ }^{\circ} \mathrm{C}$ for $7 \mathrm{~d} ; L 56^{*} D 7$ : papaya puree fermented with Leu. pseudomesenteroides 56 stored at $4{ }^{\circ} \mathrm{C}$ for $7 \mathrm{~d}$; $W 64^{*} D 7$ : papaya puree fermented with $W$. cibaria 64 stored at $4^{\circ} \mathrm{C}$ for $7 \mathrm{~d} ; L 75^{*} \mathrm{D} 7$ : papaya puree fermented with $L p b$. plantarum 75 and stored at $4{ }^{\circ} \mathrm{C}$ for $7 \mathrm{~d}$; $\mathrm{CFU} / \mathrm{g}$ : colony forming units per gram of samples.

\subsection{Organoleptic Properties of Fermented and Non-Fermented Papaya Puree}

The sensory properties of fermented and non-fermented papaya puree are presented in Figure 2. The colour perception ranged from a dull orange (1.67) to a strong bright orange colour (5.33) and was highest in the non-fermented samples at day zero. Similarly, the aroma attributes ranged from weak aroma (2.27) to strong aroma (5.07) perception and was highest in the non-fermented samples at day zero. The perception of the bright orange colour of papaya significantly decreased with storage and was influenced by the type of LAB fermenting the purees $(p \leq 0.05)$. After storage, sample $L 56^{*} D 7$ was not significantly different to the non-fermented puree at day 7 in terms of colour and aroma, while a contrary perception was made in $W 64^{*} D 7$ and $L 75^{*} D 7(p>0.05)$. The decrease in lightness could be due to browning caused by an auto-oxidation of the poly-phenolic compounds in the 
samples due to possible exposure to metal ions [28]. The lower rating in flavour, especially in Lpb. plantarum fermented samples, could be due to the fact that the cultures are known as fermentative heterolactic microorgansims that exclusively produce lactic acids [33], unlike Leu. pseudomesenteroides and W. cibaria, which are able to produce flavour compounds aside from organic acids during fermentation.

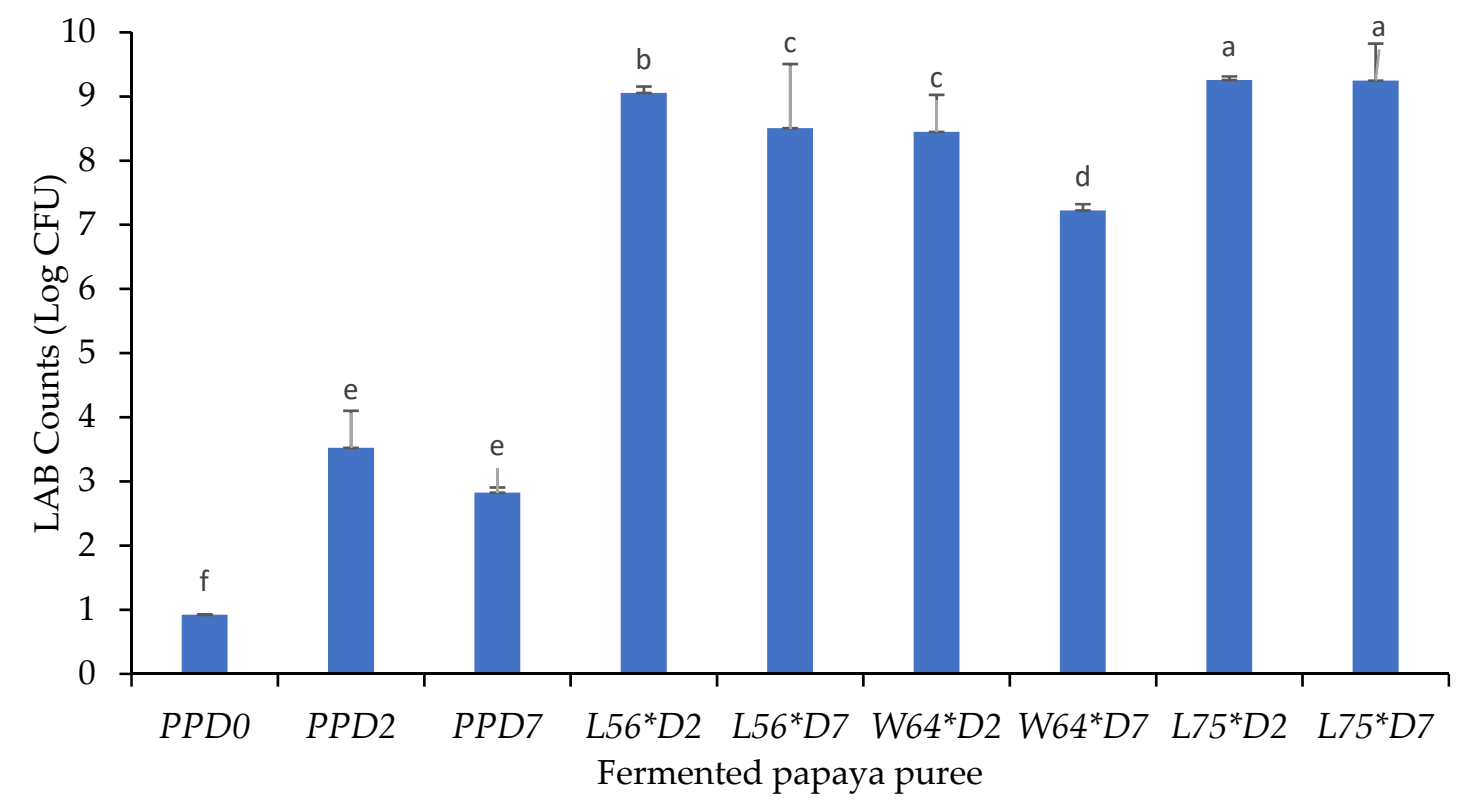

Figure 1. Surviving lactic acid bacteria counts in papaya puree. Bar with different letters are significantly different are significantly different at $p<0.05$.
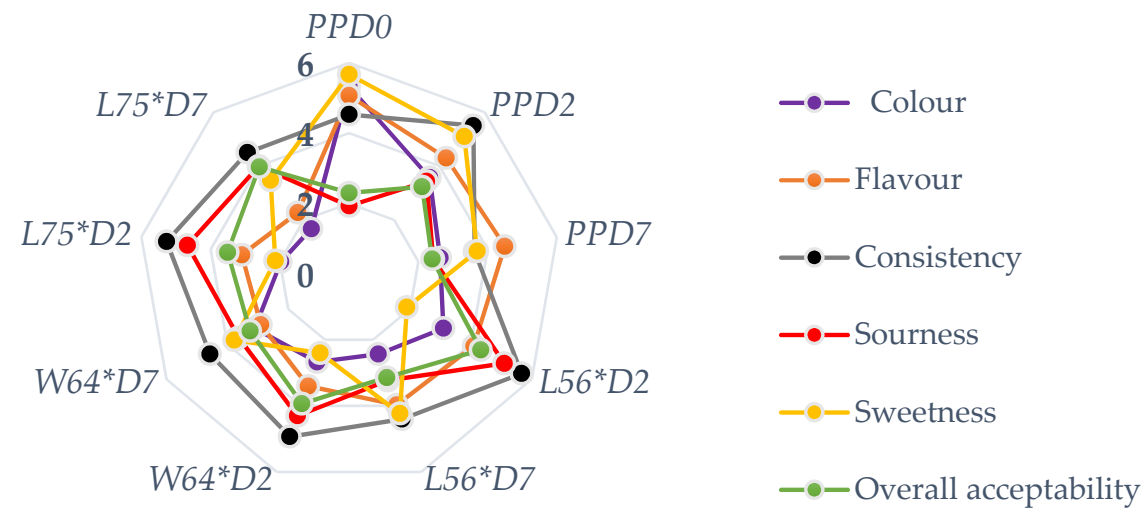

Figure 2. Sensory attributes of pasteurised and fermented papaya puree.

The consistency scores of the product ranged from moderate (3.63) to strong (5.67) and were highest in $L 56^{*} D 2$ and lowest in PPD7 puree stored for 7 days. The sourness describes the acid taste of the samples, and its perception ranged from a weak (1.93) to strong (5.10) acid taste. The perception of sour taste increased with fermentation but decreased with storage, thus supporting the lower $\mathrm{pH}$ in samples after fermentation and the upward increase in $\mathrm{pH}$ during storage. The sourness was highest in $L 56^{*} \mathrm{D} 2$; however, it was not significantly different to $L 75^{*} D 2$ and $W 64^{*} D 2$ after fermentation $(p>0.05)$, but differed to the control (PPD0, PPD2, PPD7). Sweetness is the perception of a sweet taste, and it is desirable in some foods, such as purees or juices. The sweetness ranged from weak (1.90) to strong (5.67) sucrose perception and was highest in the non-fermented samples at the start of the experiment (PPDO). The sweetness decreased with fermentation and increased during storage. This agrees with the observation made in this study on the decrease in 
TSS during fermentation and its slight increase after storage for 7 days. The increase in the sweet taste could have been a product of the de-polymerisation of polysaccharides or other complex carbohydrates in the papaya puree during storage, thus supporting the assertion that slight fermentation could proceed during cold storage, as earlier reported by Managa et al. [34]. The overall acceptability of the fermented and non-fermented stored puree was in the range of 2.30-4.33 (weak to strong) in the product. The highest acceptability was obtained in $L 56^{*} D 2$ but was not significantly different to $L 75^{*} D 7$ (3.97) stored for 7 days, which was slightly different to $L 56^{*} D 7$ and $W 64^{*} D 7$. Hence, stored puree fermented with Lpb. plantarum could deliver a probiotic and nutrient-dense and acceptable product.

Key: $P P D 0=$ non-fermented papaya puree at 0 days; $P P D 2=$ non-fermented papaya puree at day 2; L56*D2 = papaya puree fermented with Leu. pseudomesenteroides 56 for 2 days; $W 64^{*} D 2$ = papaya puree fermented with $W$. cibaria 64 for 2 days; $L 75^{*} D 2$ = papaya puree fermented with $L p b$. plantarum 75 for 2 days; $P P D 7=$ non-fermented papaya puree stored at $4{ }^{\circ} \mathrm{C}$ for $7 \mathrm{~d} ; L 56^{*} \mathrm{D} 7=$ papaya puree fermented with Leu. pseudomesenteroides 56 stored at $4{ }^{\circ} \mathrm{C}$ for $7 \mathrm{~d}$; $W 64^{*} \mathrm{D} 7=$ papaya puree fermented with $W$. cibaria 64 stored at $4{ }^{\circ} \mathrm{C}$ for $7 \mathrm{~d} ; L 75^{*} D 7=$ papaya puree fermented with $L p b$. plantarum 75 and stored at $4{ }^{\circ} \mathrm{C}$ for $7 \mathrm{~d}$.

\subsection{Changes in Phenolic Compounds and Antioxidant Power in Papaya Puree after Fermentation and Storage}

The total phenol content and antioxidant capacity and concentration of different phenolic compounds in fresh papaya puree at day 0 , non-fermented and LAB fermented papaya puree stored for $7 \mathrm{~d}$ at $4{ }^{\circ} \mathrm{C}$ are shown in Table 3.

Table 3. Changes in total phenols, antioxidant capacity and phenolic compounds of stored non-fermented and fermented papaya purees.

\begin{tabular}{|c|c|c|c|c|c|}
\hline Parameters & PPDO & PPD7 & $L 56^{*} D 7$ & $W 64^{*} D 7$ & $L 75^{*} D 7$ \\
\hline Total phenol (mg GAE/100 g FW) & $303.9 \pm 0.7^{\mathrm{e}}$ & $408.7 \pm 0.8^{\mathrm{d}}$ & $451.0 \pm 0.6^{\mathrm{c}}$ & $467.1 \pm 0.5^{b}$ & $475.1 \pm 1.9^{\mathrm{a}}$ \\
\hline FRAP $(\mu \mathrm{mol}$ TEAC $/ 100 \mathrm{~g}$ FW $)$ & $1.4 \pm 0.2^{\mathrm{c}}$ & $2.0 \pm 0.3^{b}$ & $2.0 \pm 0.3^{b}$ & $2.7 \pm 0.5^{\mathrm{a}}$ & $2.8 \pm 0.2^{\mathrm{a}}$ \\
\hline \multicolumn{6}{|l|}{ Phenolic compounds (mg/kg) } \\
\hline Gallic acid & $4.4 \pm 1.0$ & $6.7 \pm 1.5$ & $5.6 \pm 0.1$ & $2.9 \pm 0.2$ & $6.4 \pm 0.5$ \\
\hline Gallocatechin gallate & $581.4 \pm 2.7^{\mathrm{a}}$ & $564.2 \pm 1.8^{\mathrm{a}}$ & $218.9 \pm 2.4^{\mathrm{d}}$ & $462.5 \pm 9.8^{b}$ & $330.4 \pm 11.0^{b}$ \\
\hline Protocatechuic acid & $19.4 \pm 0.4^{\mathrm{b}}$ & $19.3 \pm 0.6^{\mathrm{b}}$ & $44.4 \pm 2.0^{\mathrm{a}}$ & $19.3 \pm 0.8^{b}$ & $17.4 \pm 0.1^{\mathrm{b}}$ \\
\hline Catechin & $14.21 \pm 2.3^{c}$ & $14.7 \pm 1.5^{\mathrm{c}}$ & $66.1 \pm 2.7^{\mathrm{a}}$ & $58.2 \pm 0.7^{b}$ & $51.7 \pm 1.3^{b}$ \\
\hline Epicatechin & $7.7 \pm 0.9^{b}$ & $6.2 \pm 1.2^{b, c}$ & $16.9 \pm 0.7^{\mathrm{a}}$ & $7.7 \pm 1.1^{\mathrm{b}}$ & $5.4 \pm 0.4^{\mathrm{c}}$ \\
\hline Chlorogenic acid & $19.9 \pm 0.1^{\mathrm{a}, \mathrm{b}}$ & $17.2 \pm 0.4^{\mathrm{b}}$ & $17.7 \pm 0.2^{b}$ & $1.3 \pm 0.8^{\mathrm{c}}$ & $1.7 \pm 0.2^{\mathrm{c}}$ \\
\hline Vanillic acid & $5.6 \pm 0.6^{\mathrm{a}}$ & $4.5 \pm 0.8^{\mathrm{a}}$ & $4.5 \pm 0.4^{\mathrm{a}}$ & $2.5 \pm 0.5^{b}$ & $2.5 \pm 1.1^{b}$ \\
\hline Syringic acid & $4.3 \pm 0.1$ & $4.9 \pm 0.1$ & $7.2 \pm 0.4$ & $2.5 \pm 0.1^{\mathrm{e}, \mathrm{f}}$ & $4.8 \pm 1.2^{* *}$ \\
\hline Ellagic acid & $3.9 \pm 2.0^{c}$ & $5.4 \pm 1.1^{\mathrm{b}}$ & $6.2 \pm 1.5^{b}$ & $3.1 \pm 0.2^{c}$ & $12.4 \pm 0.2^{\mathrm{a}}$ \\
\hline Quercetin & $104.9 \pm 0.1^{\mathrm{a}}$ & $103.8 \pm 16.3^{a}$ & $38.1 \pm 1.5^{\mathrm{c}}$ & $52.8 \pm 5.0^{b}$ & $57.7 \pm 2.3^{b}$ \\
\hline p-Coumaric acid & $26.9 \pm 0.2^{b}$ & $23.7 \pm 2.5^{b}$ & $37.4 \pm 3.2^{\mathrm{a}}$ & $17.3 \pm 0.8^{\mathrm{c}}$ & $25.4 \pm 0.8^{b}$ \\
\hline Ferulic acid & $15.5 \pm 0.2^{b}$ & $12.6 \pm 0.1^{d}$ & $20.5 \pm 0.1^{\mathrm{a}}$ & $13.5 \pm 0.2^{\mathrm{c}, \mathrm{d}}$ & $14.3 \pm 0.3^{b, c}$ \\
\hline
\end{tabular}

Values are mean \pm standard deviation, and means followed by a different letter within the row are significantly different $(p \leq 0.05)$; values within the brackets show \% increase or reduction in respective phenolic compounds. Key: $P P D 0=$ non-fermented papaya puree at 0 days; PPD7: non-fermented papaya puree stored at $4{ }^{\circ} \mathrm{C}$ for $7 \mathrm{~d} ; L 56^{*} \mathrm{D}$ : papaya puree fermented with Leu. pseudomesenteroides 56 stored at $4{ }^{\circ} \mathrm{C}$ for $7 \mathrm{~d}$; W64*D7: papaya puree fermented with $W$. cibaria 64 stored at $4{ }^{\circ} \mathrm{C}$ for $7 \mathrm{~d} ; L 75^{*} D 7$ : papaya puree fermented with $L p b$. plantarum 75 and stored at $4{ }^{\circ} \mathrm{C}$ for $7 \mathrm{~d}$.

The non-fermented papaya puree at $0 \mathrm{~d}$ contained the lowest TPC $(303.9 \mathrm{mg} / 100 \mathrm{~g}$ $\mathrm{DW})$, while $L 75^{*} \mathrm{D} 7$ was the highest $(475.1 \mathrm{mg} / 100 \mathrm{~g} \mathrm{DW})$ compared to the non-fermented and fermented purees stored at $4^{\circ} \mathrm{C}$ for $7 \mathrm{~d}$. The $L 56^{*} D 7$ was the lowest with regard to total phenol content $(451.0 \mathrm{mg} / 100 \mathrm{~g} \mathrm{DW})$ among the other fermented purees (W64*D7 and $\left.L 75^{*} D 7\right)$. There was an increase in the total phenol content of lactic acid in fermented plantbased food [35]. Lactic acid bacteria, such as $L p b$. plantarum, reportedly hold the ability to remove sugar moieties and hydrolysed galloyl moieties from phenolic compounds during fermentation [36]. The higher total phenol content in Lpb. plantarum-fermented papaya puree corroborates the report in Lpb. plantarum-fermented blueberry juice [37] and could be 
attributable to both the hydrolysis of glucosides to aglycones and possibly the production of esterases to which hydrolyses glycosides ester bonds, which could aid the release of insoluble bound and conjugated phenolic compounds [38] in the purees.

The Leu. pseudomesenteroides 56 could have participated in the partial conversion of simple phenolic compounds and depolymerisation of large molecular weight phenols in papaya puree [38]. To avoid the overestimation of the total phenol content through the spectrophotometric method, there were investigations performed on the changes in individual phenolic compounds during fermentation. The non-fermented puree at $0 \mathrm{~d}$, and fermented papaya puree stored at $4{ }^{\circ} \mathrm{C}$ for $7 \mathrm{~d}$ contained gallocatechin gallate, gallic acid, protocatechuic acid, vanillic acid, syringic acid, ellagic acid, chlorogenic acid, catechin, epicatechin, quercetin, p-coumaric acid and ferulic acid. Gallocatechin gallate was the most abundant phenolic compound in the non-fermented puree at $0(581.4 \mathrm{mg} / \mathrm{kg})$ and 7 days of storage $(564.2 \mathrm{mg} / \mathrm{kg})$. Gallocatechin gallate reduced significantly $(p<0.05)$ during the fermentation and storage of purees at $4{ }^{\circ} \mathrm{C}$ for $7 \mathrm{~d}$. $L 56^{*} \mathrm{D} 7$ puree had a $62.34 \%$ reduction in gallocatechin gallate compared to the non-fermented puree (PPDO). Contrary to that observed in gallocatechin gallate, an increasing trend was observed with catechin after fermentation, with $L 56^{*} D 7$ having a significantly $(p \leq 0.05)$ higher concentration $(66.1 \mathrm{mg} / \mathrm{kg})$. However, the observation suggests that Leu. pseudomesenteroides 56 could biotransform gallocatechin gallate to corresponding catechins by its esterase enzymes. The stability of catechins is $\mathrm{pH}$ dependent, and they are stable in acidic solution during lactic acid fermentation due to the production of lactic acid [39]; hence, the higher concentration of catechin in $L 56^{*} D 2$ could be due to its high acidic condition, thus resulting in the stabilisation of catechin and epicatechins. Furthermore, the disintegration of the cell wall could have further favoured the extraction of the catechins into the puree [40]. Sample $L 56^{*} D 7$ had the highest protocatechuic acid, p-coumaric acid and ferulic acid concentrations compared to the other fermented and non-fermented purees at 0 and 7 days. The increase in the phenolic acids in the other LAB-fermented purees could be due to the mobilisation of the bound phenolics to a free state via the enzymatic hydrolysis that occurs during fermentation, which could increase their bioavailability [41]. Additionally, L56*D7 and $L 75^{*} D 7$ showed a significant $(p<0.05)$ increase in vanillic and ellagic acid, respectively. The hydrolysis of ellagitannins during fermentation could have freed and increased the ellagic acid content [42]. Rodríguez et al. [43] reported the ability of LABs to decarboxylate and convert $\mathrm{p}$-coumaric acids to their corresponding vinyl derivatives, which could account for the decrease in p-coumaric acid concentrations in $W 64^{*} D 7$ and $L 75^{*} D 7$. Contrary to a four-fold increase in quercetin during fermentation initiated by Lpb. plantarum C2 in Myrtle berries [44], quercetin concentration declined during fermentation in papaya puree. Therefore, the changes in the concentration of phenolic compounds during biotrasformation and metabolic activity depend on the type of LAB strain, and the enzyme systems involved in fermentation, nutrient composition and intrinsic factors of fruit [45].

\subsection{Effect of LAB-Fermented Papaya Puree on In Vitro $\alpha$-Glucosidase Inhibition Activity}

The $\alpha$-glucosidase inhibitory activity of stored fermented and non-fermented papaya purees is presented in Figure 3. The percentage $\alpha$-glucosidase inhibitory activity ranged from $0 \%$ to $37 \%$, of which L56*D7 (37\%) was significantly $(p<0.05)$ higher than L75*D7 $(17 \%)$, while other samples had no $\alpha$-glucosidase inhibitory activity and were comparable to the non-fermented purees at 0 and 7 days. The higher concentrations of protocatechuic acid, catechin, epicatechin, caffeic acid, p-coumaric acid and ferulic acid in L56*D7 could have contributed towards the inhibition of $\alpha$-glucosidase activity. Protocatechuic acid $(\mathrm{r}=0.99, p<0.05)$, catechin $(\mathrm{r}=0.99, p<0.05)$, epicatechin $(\mathrm{r}=0.64 p<0.05)$ caffeic acid $(\mathrm{r}=0.77 p<0.05)$, $\mathrm{p}$-coumaric acid $(\mathrm{r}=0.94, p<0.05)$ and ferulic acid $(\mathrm{r}=0.94, p<0.05)$ showed a strong positive correlation with the $\alpha$-glucosidase inhibitory activity. A significant positive correlation was established between FRAP activity and $\alpha$-glucosidase $(r=0.0 .88$, $p<0.05)$. Phenolic compounds inhibited the intestinal $\alpha$-glucosidase activity, and are regarded as a mechanism to exert antidiabetic effects [46]. $\alpha$-glucosidase facilitates glucose 
absorption in the intestines; thus, inhibiting this enzyme could help to reduce the glucose absorption rate and alleviate postprandial hyperglycaemic condition [47].

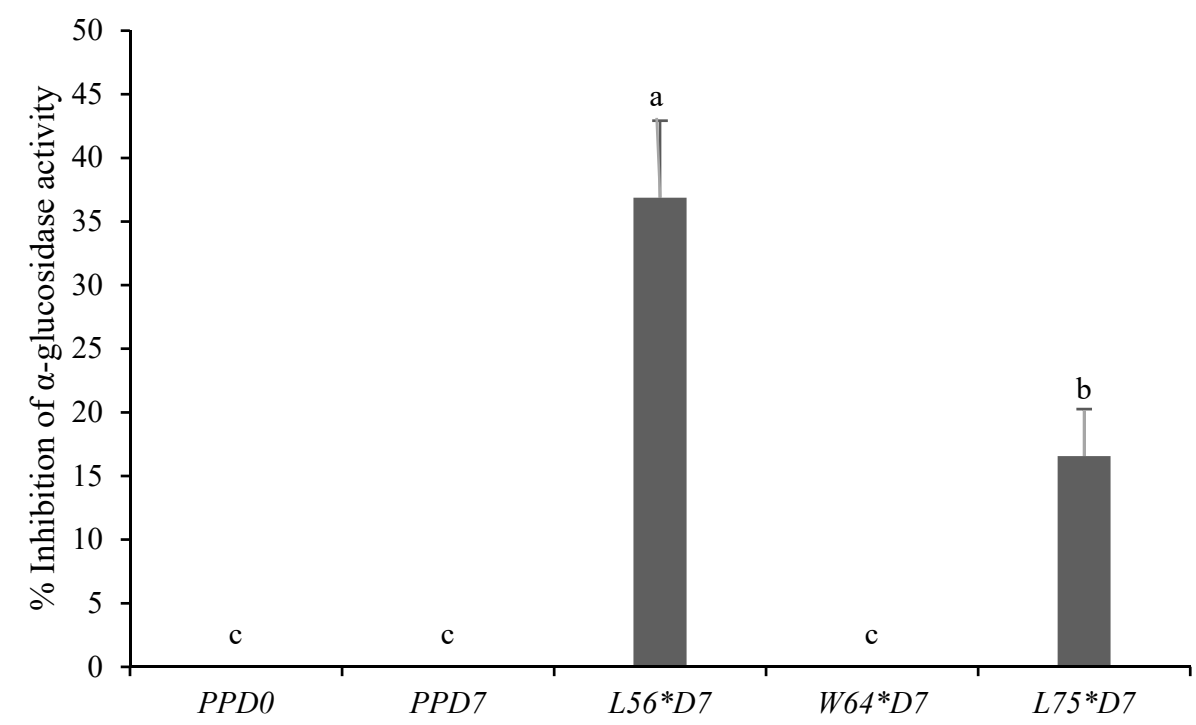

Figure 3. Inhibition of $\alpha$-glucosidase activity of $\frac{1}{2}$ diluted papaya puree fermented with different LAB strains. Bars with the same letter are not significantly different at $p<0.05$.

Data are presented as the mean and standard deviation. Bars with different letters indicate significant differences at $p \leq 0.05$. PPD0: papaya puree at 0 days of storage; PPD7: non-fermented puree stored at $4{ }^{\circ} \mathrm{C}$ for 7 days; $L 56^{*} D 7$ : papaya puree fermented with Leu. pseudomesenteroides 56 stored at $4{ }^{\circ} \mathrm{C}$ for 7 days; $W 64^{*} D 7$ : papaya puree fermented with $W$. cibaria 64 stored at $4{ }^{\circ} \mathrm{C}$ for $7 \mathrm{~d} ; L 75^{*} \mathrm{D} 7$ : papaya puree fermented with $\mathrm{Lpb}$. plantarum 75 and stored at $4{ }^{\circ} \mathrm{C}$ for $7 \mathrm{~d}$.

3.7. In Vitro-Simulated Gastrointestinal (GI) Digestion and Antioxidant Power of Fermented and Non-Fermented Papaya Puree

In order for consumers to be able to utilise the phenolic compounds in food, the increase in the bioaccessibility of polyphenols is important [48]. Therefore, the effect of digestion on the phenolic components, percent recovery and bioaccessibility of fermented and non-fermented purees at the gastric, intestinal and dialysis phase is presented in Tables 4 and 5, respectively.

At the gastric phase, the total phenol content was significantly higher $(502.4 \mathrm{mg} / 100 \mathrm{~g}$ DW) in stored $L 75^{*} D 7$ papaya puree. In general, gastric, intestinal and dialysable fractions of non-fermented and fermented puree showed significantly $(p<0.05)$ higher concentrations of phenolic content compared to the respective undigested sample (before fermentation). Therefore, the observed differences could relate to the interaction and interference of the food matrix and interactions with other dietary components, such as fibre, proteins, $\mathrm{pH}$ and the enzyme pancreatin. This observation could be due to the hydrolysis of bound phenolic compounds from carbohydrates and proteins from the food matrix facilitated by enzymatic action and low $\mathrm{pH}$ [49]. The decrease in $\mathrm{pH}$ during fermentation could have increased their stability and extractability [50].

Conversely, the observed differences in total phenol content in the gastric fraction could be due to the difference in the survival or cell population of the LAB strains in the gastrointestinal phase, which is responsible for the higher metabolism and biotransformation of most phenolic compounds [8]. However, the cell population of the LAB strains in the gastrointestinal phase were not quantified in this study. The reduction in the phenolic content in the intestinal fraction was related to the $\mathrm{pH}$ changes from acidic to alkaline $\mathrm{pH}$ [51]. Furthermore, the molecular arrangement of the different bioactive molecules or interaction effects between the bioactive compounds and other dietary compounds could have affected the total phenolic content in the dialysed fraction [9]. 
Table 4. Influence of fermentation on simulated in vitro gastrointestinal digestion of different phenolic compounds in papaya puree (mg/kg).

\begin{tabular}{|c|c|c|c|c|c|c|c|c|c|c|c|c|c|c|c|c|}
\hline \multicolumn{17}{|c|}{ Phenolic compounds in papaya puree $(\mathrm{mg} / \mathrm{kg})$} \\
\hline & \multicolumn{4}{|c|}{ PPD7 } & \multicolumn{4}{|c|}{$L 56^{*} \mathrm{D7}$} & \multicolumn{4}{|c|}{$W 64^{*} D 7$} & \multicolumn{4}{|c|}{$L 75^{*} \mathrm{D} 7$} \\
\hline Compounds & BD & GP & IP & DP & BD & GP & IP & DP & BD & GP & IP & DP & BD & GP & IP & DP \\
\hline Total phenol & $303.9 \pm 1.3 \mathrm{~g}$ & $407.4 \pm 1.7 \mathrm{de}$ & $396.3 \pm 2.3^{\mathrm{e}}$ & $135.4 \pm 0.3^{\mathrm{i}}$ & $294.7 \pm 0.1 \mathrm{~g}$ & $481.3 \pm 0.4{ }^{\mathrm{b}}$ & $411.3 \pm 0.1 \mathrm{~d}^{\mathrm{d}}$ & $400.1 \pm 1.1 \mathrm{e}$ & $380.0 \pm 0.3^{\mathrm{f}}$ & $468.2 \pm 0.1^{\mathrm{c}}$ & $367.4 \pm 1.3^{\mathrm{f}}$ & $273.4 \pm 0.5^{\mathrm{h}}$ & $395.4 \pm 0.4 \mathrm{e}^{\mathrm{e}}$ & $502.4 \pm 0.4^{\mathrm{a}}$ & $372.0 \pm 2.4 \mathrm{f}$ & $371.3 \pm 0.6^{\mathrm{f}}$ \\
\hline $\begin{array}{l}\mathrm{FRAP}(\mu \mathrm{mol} \\
\text { TEAC/ } 100 \mathrm{~g} \\
\mathrm{FW})\end{array}$ & $1.2 \pm 0.1 \mathrm{ij}$ & $3.7 \pm 0.1 \mathrm{~cd}$ & $3.5 \pm 1.1^{\mathrm{d}}$ & $1.1 \pm 1.0^{\mathrm{j}}$ & $2.0 \pm 0.3^{\mathrm{h}}$ & $2.9 \pm 0.2 \mathrm{e}$ & $2.5 \pm 0.7^{\mathrm{f}}$ & $1.4 \pm 0.0^{\mathrm{i}}$ & $2.7 \pm 0.5 \mathrm{ef}$ & $3.9 \pm 1.6 \mathrm{bc}$ & $4.0 \pm 0.1 \mathrm{~b}$ & $2.0 \pm 0.3^{\mathrm{h}}$ & $2.8 \pm 0.2 \mathrm{e}$ & $4.7 \pm 1.0^{\mathrm{a}}$ & $3.7 \pm 1.2^{\mathrm{c}}$ & $2.3 \pm 0.1 \mathrm{~g}$ \\
\hline Gallic acid & $6.7 \pm 1.5 \mathrm{f}$ & $6.1 \pm 0.2 \mathrm{f}$ & $185.0 \pm 1.0^{\mathrm{a}}$ & $73.7 \pm 2.6 \mathrm{~d}$ & $5.6 \pm 0.1 \mathrm{f}$ & $140.2 \pm 2.1 \mathrm{~b}$ & $150.9 \pm 13.5^{b}$ & $47.6 \pm 0.1 \mathrm{e}$ & $2.9 \pm 0.2^{f}$ & $89.2 \pm 1.2 \mathrm{~d}$ & $126.8 \pm 0.6^{\mathrm{C}}$ & $42.9 \pm 6.0^{\mathrm{e}}$ & $6.4 \pm 0.5^{f}$ & $57.5 \pm 0.4 \mathrm{e}$ & $139.6 \pm 0.2 \mathrm{bc}$ & $43.2 \pm 1.3^{\mathrm{e}}$ \\
\hline $\begin{array}{l}\text { Gallocatechin } \\
\text { gallate }\end{array}$ & $564.2 \pm 1.8^{\mathrm{a}}$ & $534.6 \pm 7.2^{b}$ & $264.3 \pm 4.4^{\mathrm{f}}$ & $32.9 \pm 7.6^{\mathrm{ij}}$ & $218.9 \pm 2.4^{\mathrm{f}}$ & $216.3 \pm 1.1 \mathrm{f}^{\mathrm{f}}$ & $100.4 \pm 0.7 \mathrm{~h}$ & $16.6 \pm 1.3^{j}$ & $462.5 \pm 9.8^{\mathrm{c}}$ & $447.3 \pm 7.4^{\mathrm{c}}$ & $158.6 \pm 2.3 \mathrm{~g}$ & $33.2 \pm 1.1^{\mathrm{ij}}$ & $330.4 \pm 1.9^{\mathrm{d}}$ & $311.7 \pm 22.2 \mathrm{e}$ & $111.4 \pm 9.5^{\mathrm{h}}$ & $47.8 \pm 4.4^{\mathrm{i}}$ \\
\hline $\begin{array}{l}\text { Protocatechuic } \\
\text { acid }\end{array}$ & $19.3 \pm 0.6^{\mathrm{f}}$ & $18.5 \pm 0.4 \mathrm{fg}$ & $15.4 \pm 0.5 \mathrm{fg}$ & $8.9 \pm 0.2 \mathrm{~g}$ & $44.4 \pm 2.0^{\mathrm{c}}$ & $32.1 \pm 0.4 \mathrm{de}$ & $39.8 \pm 1.8 \mathrm{~cd}$ & $15.1 \pm 0.1 \mathrm{fg}$ & $19.3 \pm 0.8 \mathrm{~g}$ & $39.4 \pm 0.7 \mathrm{~cd}$ & $66.1 \pm 6.0^{\mathrm{a}}$ & $24.7 \pm 0.6 \mathrm{e}$ & $17.4 \pm 0.1 \mathrm{fg}$ & $29.3 \pm 2.7^{\mathrm{e}}$ & $56.6 \pm 0.3^{b}$ & $18.4 \pm 0.2 \mathrm{fg}$ \\
\hline Catechin & $14.7 \pm 1.5^{\mathrm{h}}$ & $13.4 \pm 1.1 \mathrm{~h}$ & $26.6 \pm 3.5 \mathrm{gh}$ & $5.5 \pm 0.2 \mathrm{~h}$ & $66.1 \pm 2.7 \mathrm{de}$ & $139.2 \pm 5.5^{\mathrm{c}}$ & $211.4 \pm 9.8^{\mathrm{b}}$ & $39.5 \pm 1.2^{\mathrm{fg}}$ & $58.2 \pm 0.7 \mathrm{ef}$ & $84.2 \pm 6.4^{\mathrm{d}}$ & $137.4 \pm 7.9^{\mathrm{c}}$ & $41.1 \pm 2.3^{\mathrm{fg}}$ & $51.7 \pm 1.3 \mathrm{ef}$ & $121.9 \pm 5.4^{\mathrm{c}}$ & $277.5 \pm 6.66^{\mathrm{a}}$ & $68.3 \pm 2.7 \mathrm{de}$ \\
\hline $\begin{array}{l}\text { Chlorogenic } \\
\text { acid }\end{array}$ & $17.2 \pm 0.4 \mathrm{~b}$ & $22.1 \pm 0.2 \mathrm{a}$ & $8.0 \pm 0.1^{\mathrm{c}}$ & $2.2 \pm 0.1 \mathrm{e}$ & $17.7 \pm 0.2^{\mathrm{b}}$ & $3.5 \pm 1.4 \mathrm{e}$ & $7.6 \pm 0.1^{\mathrm{c}}$ & $0.7 \pm 0.2 \mathrm{e}$ & $1.3 \pm 0.8 \mathrm{ef}$ & $5.9 \pm 2.2^{\mathrm{d}}$ & $10.0 \pm 3.3^{c}$ & $4.8 \pm 0.4 \mathrm{de}$ & $1.7 \pm 0.2 \mathrm{e}$ & $5.6 \pm 1.0^{\mathrm{d}}$ & $10.0 \pm 0.1^{\mathrm{c}}$ & $4.2 \pm 0.2 \mathrm{de}$ \\
\hline Vanillic acid & $4.5 \pm 0.8^{\mathrm{c}}$ & $4.9 \pm 0.5^{c}$ & $2.5 \pm 0.1 \mathrm{~cd}$ & $1.1 \pm 0 . \mathrm{d}^{\mathrm{d}}$ & $4.5 \pm 0.4^{\mathrm{c}}$ & $4.1 \pm 0.8^{c}$ & $4.8 \pm 0.2^{c}$ & $2.1 \pm 0.1 \mathrm{~cd}$ & $2.5 \pm 0.5 \mathrm{~cd}$ & $5.4 \pm 2.0 \mathrm{bc}$ & $7.5 \pm 0.3 \mathrm{bc}$ & $2.5 \pm 0.1 \mathrm{~cd}$ & $2.5 \pm 1.1 \mathrm{~cd}$ & $9.7 \pm 0.9 \mathrm{ab}$ & $12.7 \pm 0.2^{\mathrm{a}}$ & $2.5 \pm 0.3^{\mathrm{cd}}$ \\
\hline Syringic acid & $4.9 \pm 0.1 \mathrm{e}$ & $5.1 \pm 1.2 \mathrm{e}$ & $17.3 \pm 0.4 \mathrm{~cd}$ & $8.2 \pm 1.0 \mathrm{e}$ & $7.2 \pm 0.4 \mathrm{e}$ & $7.9 \pm 1.6 \mathrm{e}$ & $20.3 \pm 1.5^{\mathrm{c}}$ & $13.5 \pm 0.8^{\mathrm{d}}$ & $2.5 \pm 0.1 \mathrm{ef}$ & $3.7 \pm 0.6 \mathrm{ef}$ & $19.3 \pm 0.9 \mathrm{~cd}$ & $3.4 \pm 0.1 \mathrm{ef}$ & $4.8 \pm 1.2^{\mathrm{ef}}$ & $35.2 \pm 1.4 \mathrm{a}$ & $29.3 \pm 0.9 \mathrm{~b}$ & $1.2 \pm 1.2^{\mathrm{f}}$ \\
\hline Ellagic acid & $5.4 \pm 1.1^{\mathrm{d}}$ & $5.6 \pm 0.3^{\mathrm{cd}}$ & $11.2 \pm 0.7^{\mathrm{c}}$ & $8.1 \pm 0.7 \mathrm{~cd}$ & $6.2 \pm 1.5^{\mathrm{cd}}$ & $4.3 \pm 2.0^{\mathrm{d}}$ & $13.3 \pm 0.9 \mathrm{bc}$ & $7.1 \pm 0.1 \mathrm{~cd}$ & $3.1 \pm 0.2^{\mathrm{d}}$ & $4.8 \pm 1.3^{\mathrm{d}}$ & $12.2 \pm 0.4 \mathrm{bc}$ & $6.2 \pm 0.4 \mathrm{~cd}$ & $12.4 \pm 0.2 \mathrm{bc}$ & $19.3 \pm 2.4^{\mathrm{b}}$ & $29.1 \pm 0.7 \mathrm{a}$ & $2.8 \pm 0.6^{\mathrm{d}}$ \\
\hline Quercetin & $103.8 \pm 16.3^{\mathrm{a}}$ & $87.5 \pm 2.3^{b}$ & $62.8 \pm 0.9^{\mathrm{c}}$ & $38.1 \pm 0.8^{f}$ & $38.1 \pm 1.5^{\mathrm{f}}$ & $31.7 \pm 1.7 \mathrm{fg}$ & $27.4 \pm 2.9 \mathrm{gh}$ & $15.9 \pm 0.4^{\mathrm{i}}$ & $52.8 \pm 5.0 \mathrm{e}$ & $58.1 \pm 2.4 \mathrm{de}$ & $63.2 \pm 3.1 \mathrm{~cd}$ & $25.9 \pm 0.8 \mathrm{~g}$ & $57.7 \pm 2.3 \mathrm{de}$ & $68.9 \pm 2.1 \mathrm{bc}$ & $73.5 \pm 3.1 \mathrm{~b}$ & $18.8 \pm 2.3 \mathrm{hi}$ \\
\hline $\begin{array}{c}\text { p-Coumaric } \\
\text { acid }\end{array}$ & $23.7 \pm 2 . \mathrm{ef}^{\mathrm{ef}}$ & $21.6 \pm 0.7^{\text {ef }}$ & $113.8 \pm 10.0^{\mathrm{a}}$ & $54.4 \pm 0.9^{\mathrm{c}}$ & $37.4 \pm 3.2^{\mathrm{d}}$ & $32.5 \pm 0.6 \mathrm{de}$ & $29.0 \pm 1.6 \mathrm{de}$ & $16.7 \pm 0.5^{\mathrm{f}}$ & $17.3 \pm 0.8^{\mathrm{f}}$ & $74.2 \pm 1.6^{\mathrm{C}}$ & $87.2 \pm 0.7^{b}$ & $24.0 \pm 5.8^{\text {ef }}$ & $25.4 \pm 0.8^{\text {ef }}$ & $58.1 \pm 3.7^{c}$ & $84.4 \pm 2.7^{\mathrm{b}}$ & $17.5 \pm 0.9^{\mathrm{f}}$ \\
\hline Ferulic acid & $12.6 \pm 0.1 \mathrm{f}$ & $13.4 \pm 0.9$ ef & $15.8 \pm 0.2^{\mathrm{e}}$ & $6.0 \pm 0.1 \mathrm{~g}$ & $20.5 \pm 0.1 \mathrm{bc}$ & $18.9 \pm 1.1 \mathrm{~cd}$ & $17.2 \pm 0.5 \mathrm{de}$ & $11.5 \pm 0.3^{\mathrm{f}}$ & $13.5 \pm 0$. ef $^{-1}$ & $15.0 \pm 0.8^{\mathrm{e}}$ & $18.9 \pm 0.1 \mathrm{~cd}$ & $7.0 \pm 0.7 \mathrm{~g}$ & $14.3 \pm 0.3^{\mathrm{e}}$ & $19.2 \pm 1.1^{\mathrm{c}}$ & $27.4 \pm 0.4^{\mathrm{a}}$ & $12.1 \pm 0.2^{\mathrm{f}}$ \\
\hline
\end{tabular}

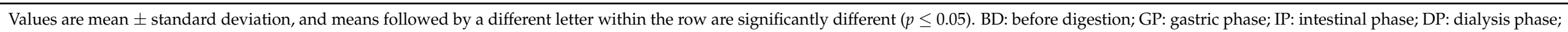

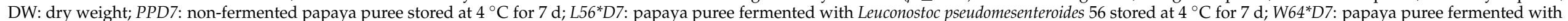
Weissella cibaria 64 stored at $4{ }^{\circ} \mathrm{C}$ for $7 \mathrm{~d} ; L 75^{*} D 7$ : papaya puree fermented with Lpb. plantarum 75 and stored at $4{ }^{\circ} \mathrm{C}$ for $7 \mathrm{~d}$. 
Table 5. Recovery and bioaccessibility (\%) of different phenolic compounds in fermented and non-fermented papaya puree.

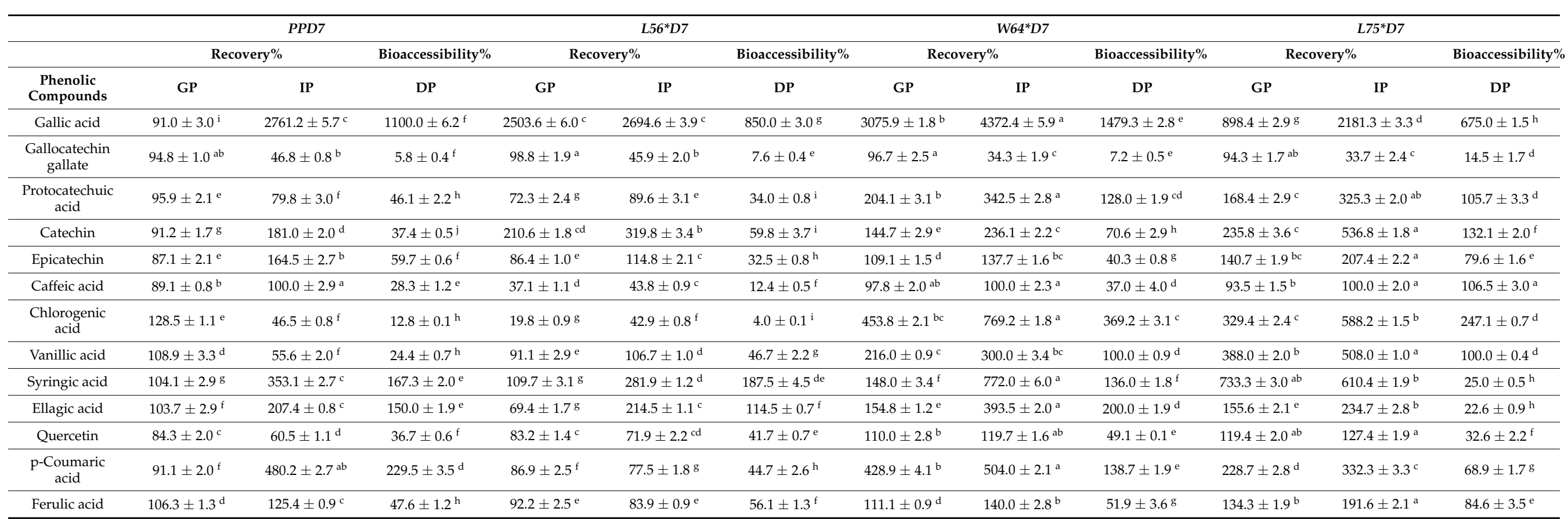

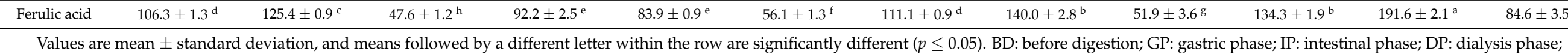

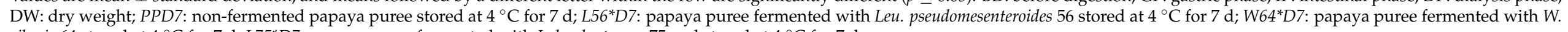
cibaria 64 stored at $4{ }^{\circ} \mathrm{C}$ for $7 \mathrm{~d} ; L 75^{*} \mathrm{D}$ : papaya puree fermented with $L \mathrm{pb}$. plantarum 75 and stored at $4{ }^{\circ} \mathrm{C}$ for $7 \mathrm{~d}$. 
The undigested non-fermented puree stored for 7 days at $4{ }^{\circ} \mathrm{C}$ contained the highest concentration of gallocatechin gallate $(564.2 \mathrm{mg} / \mathrm{kg})$, and its concentration significantly $(p<0.05)$ decreased with fermentation, while $W 64^{*} D 7$-fermented puree had the highest concentration $(462.5 \mathrm{mg} / \mathrm{kg})$. The gallocatechin gallate concentration at the intestinal phase of all fermented and non-fermented purees showed a substantial reduction, varying from 264.3 to $100.4 \mathrm{mg} / \mathrm{kg}$ compared to the gastric fraction and the undigested purees. The \% recovery of gallocatechin gallate in the intestinal fraction was $46.8 \%, 45.9 \%, 34.3 \%$ and $33.7 \%$ in $P P D 7, L 56^{*} D 7, W 64^{*} D 7$ and $L 75^{*} D 7$, respectively, while $14.5 \%$ was recovered in the $L 75^{*} D 7$ dialysed fraction. The intestinal fractions of non-fermented and fermented purees showed a substantial increase in gallic acid concentration compared to the undigested and gastric fractions. The amount of gallic acid bioaccessible in the dialysable fraction of the non-fermented puree was $1100.0 \%$ compared to its undigested sample. The $\%$ recovery of gallic acid in the dialysed fractions of $W 64^{*} D 7, L 56^{*} D 7$ and $L 75^{*} D 7$ was $1479.3 \%, 850 \%$ and $675.0 \%$, respectively.

Krook and Hagerman [51] reported the stability of epigallocatechin-O-gallate at $\mathrm{pH}<1.5$ and $5-6$, and its degradation at $\mathrm{pH}$ higher than seven produced gallic acid. Therefore, it can be hypothesised that the gallocatechin gallates could be stable at $\mathrm{pH} 2$, and at $\mathrm{pH} 7$ due to its instability, and could undergo decomposition that produces gallic acid, especially at the intestinal phase. Furthermore, Liu et al. [52] also showed that the increase in gallic acid due to alkaline hydrolysis could had released the bound phenolic acids, thus increasing their bioavailability. On the contrary, Tagliazucchi et al. [52] and Jara-Palacios et al. [53] reported the degradation of gallic acid at the intestinal phase. However, the $L 56^{*} D 7$ and $L 75^{*} D 7$ could have partially metabolised, thereby reducing the $\%$ recovery of gallic acid in the intestinal fraction of the fermented purees.

Similar to the report of Jara-Palacios et al. [53] on the higher concentration of protocatechuic acid in the intestinal digests of Zalema grapes (Vitis vinifera sp.) pomace. Lui et al. [54] also showed increased extraction of phenolic acids under mild alkaline conditions.

In this study, samples $W 64^{*} D 7$ and $L 75^{*} D 7$ had higher protocatechuic acid concentrations than the undigested samples (PPD7). Additionally, the higher gallic acid concentration at the intestinal phase indicates that the gallic acid did not undergo a dehydroxylation process for the production of protocatechuic acid [9]. There was a significantly higher concentration of protocatechuic acid in the $W 64^{*} D 7$ and $L 75^{*} D 7$ at the gastric phase $(p<0.05)$ than the $L 56^{*} D 7$. The \% recovery of protocatechuic acid was significantly higher in the $W 64^{*} D 7-(342.5 \%)$ and $L 75^{*} D 7(325.3 \%)$-fermented purees at the intestinal phase compared to the $L 56^{*} D 7$ and undigested purees $(p \leq 0.05)$. W6 $64^{*} D 7$ and $L 75^{*} D 7$ had a significantly higher \% recovery of protocatechuic acid at the dialysis phase compared to the other samples. It is possible that the protocatechuic acid could have been partially metabolised by $L 56^{*} D 7$ during gastric digestion, since it was reduced from 44.4 to $32.1 \mathrm{mg} / \mathrm{kg}$.

Catechin concentration increased in the gastric fraction of the fermented puree. This could be due to the lower $\mathrm{pH}$ of the fermented purees and the lower gastric $\mathrm{pH}$, which resulted in stable catechin molecules [52]. At the same time, catechin concentration increased significantly in the intestinal fractions of fermented purees. The intestinal fraction of $L 75^{*} D 7$ showed a significantly higher amount $(277.5 \mathrm{mg} / \mathrm{kg})$ of catechins with $536.8 \%$ recovery. Moreover, the dialysable fraction of $L 75^{*} D 7$ showed the highest bioaccessible catechin $(132.1 \%)$ compared to the undigested, digested fermented and non-fermented purees. The stability of catechins has been correlated with the $\mathrm{pH}$ and are reported to be stable in acidic conditions, and unstable at $\mathrm{pH}$ greater than or near neutral [55]. The observed increase in catechin in the intestinal fraction in this study could be due to the spontaneous degradation of gallocatechins at alkaline $\mathrm{pH}[9]$.

The percentage recovery of ellagic acid in the gastric fraction of L56 ${ }^{*} D 7(69.4 \%)$ was lower when compared to its undigested sample (103.7\%), W64*D7 (154.8\%) and $L 75^{*} D 7$ $(155.6 \%)$. This suggests the possible utilisation of ellagic acid by $L 56^{*} D 7$. Conversely, the $\%$ of ellagic acid was significantly $(p<0.05)$ increased in the intestinal fractions of the 
non-fermented and fermented puree compared to their undigested samples. The observed increase in ellagic acid concentration could be due to the hydrolysis of ellagitannins from the food matrix to ellagic acid due to the mild alkaline $\mathrm{pH}(7.5)$ at the intestinal phase [56]. The highest \% bioaccessibility of ellagic acid was in the $W 64^{*} D 7$ (200.0\%) dialysed fraction and was significantly different to the dialysed digest of the other purees. The observed lower \% bioaccessibility (22.6\%) of ellagic acid in the dialysed fraction of $L 75^{*} D 7$ digest could be due to the possible utilisation of ellagic acid during fermentation caused by $L p b$. plantarum. Lactobacillus spp. reportedly has the ability to utilise ellagic acid and glycosyl ellagic acid during metabolism [57].

Furthermore, the percentage recovery of chlorogenic acid and syringic acid was significantly higher in the intestinal fraction of $W 64^{*} D 7(769.2 \% ; 772.0 \%)$, with the highest $\%$ bioaccessible amount of $369.2 \%$ chlorogenic acid and $136.0 \%$ syringic acid at the dialysis phase. Moreover, fermentation increased the \% recovery of vanillic acid in the intestinal fractions and was highest in $L 75^{*} D 7$ (508.0\%). The highest percentage bioaccessible content of $100 \%$ was obtained in $W 64^{*} D 7$ and $L 75^{*} D 7$ in the dialysable fractions of fermented purees. The increase in ellagic, chlorogenic, syringic and vanillic acid concentrations after intestinal digestion could be due to their release from their bound form in the food matrix due to enzymatic digestion [9]. The decrease in chlorogenic acid, ellagic acid and ferulic acid in $L 56^{*} D 7$ at the gastric phase could be due to the partial use of these compounds during metabolism.

LAB fermentation caused an increase in the quercetin content of fermented purees compared to the non-fermented purees. The percentage recovery of quercetin content was higher in the W64*D7 $(119.7 \% ; 110.0 \%)$ and $L 75^{*} D 7(127.4 \% ; 119.4 \%)$ compared to $L 56^{*} D 7(71.9 \% ; 83.2 \%)$ and PPD7 $(60.5 \% ; 84.3 \%)$ at both intestinal and gastric phases, respectively. $L 75^{*} D 7$ had the highest \% recovery of quercetin at the intestinal phase and was not significantly different to $W 64^{*} D 7(p>0.05)$. Likewise, the dialysable fractions of $L 56^{*} D 7(41.7 \%)$ and $W 64^{*} D 7$, despite being high, were not significantly different to one another $(p>0.05)$. A similar non-significant change in the quercetin content was reported during the gastric and intestinal phase digestion of onions [58]. These results, therefore, suggest that the $\mathrm{pH}$ change during fermentation and during the gastric, intestinal phases and the action of digestive enzymes (pancreatin), could have participated in the release of quercetin from the food matrix [58]. The degree of metabolization by different LAB strains used in this study varied, as reflected in the p-coumaric acid concentration found in the fermented samples. The observed non-significant reduction in p-coumaric acid in the undigested $L 56^{*} D 7$ puree could be due to the decarboxylation of ferulic acid [59].

The intestinal and dialysed fractions of $W 64^{*} D 7$ had the highest p-coumaric acid \% recovery $(504.0 \%)$ and \% bioaccessibility $(138.7 \%)$ and were significantly higher than those of other purees. A possible reason for the higher recovery of ferulic acid at the dialysis phase, with respect to the undigested samples, could be due to an interference from the food matrix and the reduced esterification of ferulic acid with sugar moieties after digestion [60]. Similarly, a higher \% recovery of ferulic acid was observed in $W 64^{*} D 7$ and $L 75^{*} D 7$ intestinal fractions than their respective gastric fractions. $L 75^{*} D 7$ had the highest $\%$ bioaccessible ferulic acid at the dialysable fraction. The observed decrease in the \% recovery of different phenolic constituents at the intestinal phase in $L 56^{*} D 7$ suggests a partial metabolism of the phenolic compound. Valero-Cases et al. [8] previously reported the impact of LAB fermentation on the in vitro digestion and biotransformation of phenolic compounds in fermented pomegranate juices. Therefore, the relationship among the concentrations of phenolic compounds in fermented puree could be correlated with the increased LAB survival in $L 75^{*} D 7$ and $L 56^{*} D 7$ during and after fermentation.

\subsection{Effect of Fermentation and In Vitro Digestion on the Antioxidant Capacity of Papaya Puree}

The types of transformations, such as epimerisation, degradation, oxidation and hydrolysis, during the fermentation and gastrointestinal digestion can affect the phenolic content and its structure [8]. Fermentation with LAB strains increased the antioxidant 
capacity (FRAP values) of papaya purees, with the exception of $L 56^{*} D 7$. During gastric digestion, the FRAP values of $P P D 7, W 65^{*} D 7$ and $L 75^{*} D 7$ significantly $(p \leq 0.05)$ increased, compared to the undigested samples. The highest FRAP antioxidant power was obtained in the gastric fraction of $L 75^{*} D 7(4.7 \mu \mathrm{mol}$ TEAC $/ 100 \mathrm{~g} \mathrm{FW})$, while a significant $(p \leq 0.05)$ decrease in FRAP was observed in the intestinal fractions of $L 56^{*} D 7$ and $L 75^{*} D 7$, but not $W 64^{*} D 7$, when compared to the gastric fractions. The FRAP values in the dialysable fractions range was lowest in PPD7 $\left(1.1 \mu \mathrm{mol}\right.$ TEAC/100 g FW) and highest in $L 75^{\circ} D 7$ $(2.3 \mu \mathrm{mol}$ TEAC $/ 100 \mathrm{~g} \mathrm{FW})$. The findings in this study confirm that fermentation with Lpb. plantarum 75 and W. cibaria 64 increases the FRAP activity due to the contribution of the free soluble antioxidants. The FRAP activity and total phenol content are positively correlated [46]. The metal chelating properties of phenolic constituents contributed to the antioxidant activity of $W 64^{*} D 7$ and $L 75^{*} D 7$, which can be justified by the increase in most phenolic constituents compared to in the $L 56^{*} D 7$ and non-fermented papaya puree.

\section{Conclusions}

The results presented in this study showed that the fermentation of papaya puree by W. cibaria 64 and Lpb. plantarum 75 improves antioxidant capacity (FRAP activity) due to the increase in phenolic constituents compared to the Leu. pseudomesenteroides 56 and non-fermented papaya puree. However, the viability of all LAB strains used in this study after in vitro digestion requires investigation. This study provided important information on the estimation based on the percentage recovery of different phenolic constituents that are available for in vivo absorption after the consumption of LAB-fermented papaya puree. However, further investigations are necessary in the survival of LABs; antioxidant activity after in vitro digestion and the bioaccessibility of phenolic constituents after digestion could be investigated using Caco-2 cellular models to confirm the uptake of phenolic and carotenoid components. Based on the phenolics profiles, antioxidants, LAB survival and quality parameters of the purees, the study recommends that local food manufacturers in Reunion Island use $\mathrm{Lpb}$. plantarum 75 for the fermentation of papaya purees for optimum nutrient bioaccessiblity and functional benefits from locally produced papaya.

Supplementary Materials: The following are available online at https:/ / www.mdpi.com/article/10 $.3390 /$ foods10050962/s1, Table S1: The identification of different phenolic compounds.

Author Contributions: F.M.M.--performed the analysis and wrote the first draft; S.A.A.- executed the data validation, visualisation and revised the fermentation part of the article; V.E.M.- executed the data validation of the HPLC analysis and data presentation; C.G.-guidance and methodology for in vitro intestinal investigation; F.R.-was responsible for the supervision of the fermentation analysis; R.M.S.- edited the manuscript; D.S.- conceptualisation, project administration, data validation and final editing. All authors have read and agreed to the published version of the manuscript.

Funding: Authors acknowledged the financial support from the Department of Science and Innovation, the Government of South Africa and the National Research Foundation (grant number 98352) for the Phytochemical Food Network to Improve Nutritional Quality for Consumers.

Institutional Review Board Statement: Not applicable.

Informed Consent Statement: Not applicable.

Data Availability Statement: Data is contained within the article or Supplementary Materials. The data presented in this study are available in the article and also in supplementary file Table S1 attached in the manuscript.

Conflicts of Interest: The authors declare no conflict of interest.

\section{References}

1. Slavin, L.J.; Lloyd, B. Health Benefits of Fruits and Vegetables. Adv. Nutr. 2012, 3, 506-516. [CrossRef] [PubMed]

2. Report of a Joint FAO/WHO Workshop, 1-3 September 2004, Kobe, Japan. Available online: https://apps.who.int/iris/ bitstream/handle/10665/43143/9241592818_eng.pdf;jsessionid=6D4B987B3DCB6B4F0306374D1EA9A570?sequence=1 (accessed on 21 February 2021). 
3. Fessard, A.; Kapoor, A.; Patche, J.; Assemat, S.; Hoarau, M.; Bourdon, E.; Bahorun, T.; Remize, F. Lactic fermentation as an efficient tool to enhance the antioxidant activity of tropical fruit juices and teas. Microorganisms 2017, 5, 23. [CrossRef]

4. Di Cagno, R.; Minervini, G.; Rizzello, C.G.; De Angelis, M.; Gobbetti, M. Effect of lactic acid fermentation on antioxidant, texture, color and sensory properties of red and green smoothies. Food Microbiol. 2011, 28, 1062-1071. [CrossRef]

5. Filannino, P.; Azzi, L.; Cavoski, I.; Vincentini, O.; Rizzello, C.G.; Gobbetti, M.; Di Cagno, R. Exploitation of the health-promoting and sensory properties of organic pomegranate (Punica granatum L.) juice through lactic acid fermentation. Int. J. Food Microbiol. 2013, 163, 184-192. [CrossRef]

6. Evans, E.A.; Ballen, F.H.; Crane, J.H. An Overview of US Papaya Production, Trade, and Consumption. FE914, one of a series of the Food and Resource Economics Department, UF/IFAS Extension. Available online: https://edis.ifas.ufl.edu/pdffiles/FE/FE9 1400.pdf (accessed on 23 February 2021).

7. Xiang, H.; Sun-Waterhouse, D.; Waterhouse, G.I.N.; Cui, C.; Ruan, Z. Fermentation-enabled wellness foods: A fresh perspective. Food Science and Human Wellness, a fresh perspective. Food Sci. Hum. Wellness 2019, 8, 203-243. [CrossRef]

8. Valero-Cases, E.; Nuncio-Jáuregui, N.; José Frutos, M. Influence of fermentation with different lactic acid bacteria and in vitro digestion on the biotransformation of phenolic compounds in fermented pomegranate juices. J. Agric. Food Chem. 2017, 65, 6488-6496. [CrossRef]

9. Mosele, J.I.; Macià, A.; Romero, M.P.; Motilva, M.J.; Rubió, L. Application of in vitro gastrointestinal digestion and colonic fermentation models to pomegranate products (juice, pulp and peel extract) to study the stability and catabolism of phenolic compounds. J. Funct. Foods 2015, 14, 529-540. [CrossRef]

10. Shahidi, F.; Peng, H. Bioaccessibility and bioavailability of phenolic compounds. J. Food Bioact. 2018, 4, 11-68. [CrossRef]

11. Pavan, V.; Sancho, R.A.S.; Pastore, G.M. The effect of in vitro digestion on the antioxidant activity of fruit extracts (Carica papaya, Artocarpus heterophillus and Annona marcgravii). LWT Food Sci. Technol. 2014, 59, 1247-1251. [CrossRef]

12. Patthamakanokporn, O.; Puwastien, P.; Nitithamyong, A.; Sirichakwal, P.P. Changes of antioxidant activity and total phenolic compounds during storage of selected fruits. J. Food Compos. Anal. 2008, 21, 241-248. [CrossRef]

13. Gayosso-Garcia Sancho, L.E.; Yahia, E.M.; González-Aguilar, G.A. Identification and quantification of phenols, carotenoids and vitamin C from papaya (Carica papaya L. cv. Maradol) fruit determined by HPLC-DAD-MS/MS ESI. Food Res. Int. 2011, 44, 1284-1291. [CrossRef]

14. Casirola, D.M.; Ferraris, R.P. $\alpha$-Glucosidase inhibitors prevent diet-induced increases in intestinal sugar transport in diabetic mice. Metabolism 2006, 55, 832-841. [CrossRef] [PubMed]

15. Danese, C.; Esposito, D.; D’Alfonso, V.; Cirene, M.; Ambrosino, M.; Colotto, M. Plasma glucose level decreases as collateral effect of fermented papaya preparation use. Clin. Ter. 2006, 157, 195-198. [PubMed]

16. Managa, G.M.; Remize, F.; Garcia, C.; Sivakumar, D. Effect of Moist Cooking Blanching on Colour, Phenolic Metabolites and Glucosinolate Content in Chinese Cabbage (Brassica rapa L. subsp. chinensis). Foods 2019, 8, 399. [CrossRef]

17. Cabello-Olmo, M.; Oneca, M.; Torre, P.; Díaz, J.V.; Encio, I.J.; Barajas, M.; Araña, M. Influence of storage temperature and packaging on bacteria and yeast viability in a plant-based fermented food. Foods 2020, 9, 302. [CrossRef] [PubMed]

18. Oliveira, A.D.N.; Ramos, A.M.; Minim, V.P.R.; Chaves, J.B.P. Sensory stability of whole mango juice: Influence of temperature and storage time. Food Sci. Technol. 2012, 32, 819-825. [CrossRef]

19. Brodkorb, A.; Egger, L.; Alminger, M.; Alvito, P.; Assunção, R.; Ballance, S.; Bohn, T.; Bourlieu-Lacanal, C.; Boutrou, R.; Carrière, F.; et al. INFOGEST static in vitro simulation of gastrointestinal food digestion. Nat. Protoc. 2019, 14, 991-1014. [CrossRef] [PubMed]

20. Palafox-Carlos, H.; Gil-Chávez, J.; Sotelo-Mundo, R.R.; Namiesnik, J.; Gorinstein, S.; González-Aguilar, G.A. Antioxidant interactions between major phenolic compounds found in 'Ataulfo' mango pulp: Chlorogenic, gallic, protocatechuic and vanillic acids. Molecules 2012, 17, 12657-12664. [CrossRef]

21. Zhang, L.; Li, J.; Hogan, S.; Chung, H.; Welbaum, G.E.; Zhou, K. Inhibitory effect of raspberries on starch digestive enzymes and their antioxidant properties and phenolic composition. Food Chem. 2010, 119, 592-599. [CrossRef]

22. Ayed, L.; Abid, S.B.; Hamdi, M. Development of a beverage from red grape juice fermented with the Kombucha consortium. Ann. Microbiol. 2017, 67, 111-121. [CrossRef]

23. Dimitrellou, D.; Kandylis, P.; Kokkinomagoulos, E.; Hatzikamari, M.; Bekatorou, A. Emmer-Based Beverage Fortified with Fruit Juices. Appl. Sci. 2021, 1, 3116. [CrossRef]

24. Soibam, H.; Ayam, V.S.; Chakraborty, I. Preparation, and evaluation of wine from sugarcane and beet juice. Adv. Biores. 2017, 8 . [CrossRef]

25. Bhardwaj, R.; Mukherjee, S. Effects of fruit juice blending ratios on kinnow juice preservation at ambient storage condition. Afr. J. Food Sci. 2011, 5, 281-286.

26. Jan, A.; Masih, E.D. Development and quality evaluation of pineapple juice blend with carrot and orange juice. Int. J. Sci. Res. 2012, 2, 1-8.

27. Persic, M.; Mikulic-Petkovsek, M.; Slatnar, A.; Veberic, R. Chemical composition of apple fruit, juice and pomace and the correlation between phenolic content, enzymatic activity and browning. LWT Food Sci. Technol. 2017, 82, 23-31. [CrossRef]

28. Mellican, R.I.; Li, J.; Mehansho, H.; Nielsen, S.S. The role of iron and the factors affecting off-color development of polyphenols. J. Agric. Food Chem. 2003, 51, 2304-2316. [CrossRef]

29. De Vries, M.C.; Vaughan, E.E.; Kleerebezem, M.; de Vos, W.M. Lactobacillus plantarum—Survival, functional and potential probiotic properties in the human intestinal tract. Int. Dairy J. 2006, 16, 1018-1028. [CrossRef] 
30. Cebeci, A.; Gürakan, C. Properties of potential probiotic Lactobacillus plantarum strains. Food Microbiol. 2003, 20, 511-518. [CrossRef]

31. Srisukchayakul, P.; Charalampopoulos, D.; Karatzas, K.A. Study on the effect of citric acid adaptation toward the subsequent survival of Lactobacillus plantarum NCIMB 8826 in low pH fruit juices during refrigerated storage. Food Res. Int. 2018, 111, 198-204. [CrossRef]

32. Codex Standard, Codex General Standard for Fruit Juices and Nectars. 2005. Available online: www.codexalimentarius.net/ (accessed on 23 February 2021).

33. Chen, P.T.; Hong, Z.S.; Cheng, C.L.; Ng, I.S.; Lo, Y.C.; Nagarajan, D.; Chang, J.S. Exploring fermentation strategies for enhanced lactic acid production with polyvinyl alcohol-immobilized Lactobacillus plantarum 23 using microalgae as feedstock. Bioresour. Technol. 2020, 308, 123266. [CrossRef] [PubMed]

34. Managa, G.M.; Akinola, S.A.; Remize, F.; Garcia, C.; Sivakumar, D. Lactobacillus fermentation and bioaccessibility changes physicochemical parameters and bioaccessibility of lactic acid bacteria fermented chayote leave (Sechium edule) and pineapple (Ananas comosus) smoothie. Front. Nutr. 2021, 8, 120. [CrossRef]

35. Hur, S.J.; Lee, Y.; Kim, Y.; Choi, I.; Kim, G. Effect of fermentation on the antioxidant activity in plant-based foods. Food Chem. 2014, 160, 346-356. [CrossRef] [PubMed]

36. Muñoz, R.; de Las Rivas, B.; de Felipe Toledano, F.L.; Reverón, I. Biotransformation of phenolics by Lactobacillus plantarum in fermented foods. In Fermented Foods in Health and Disease Prevention; Frías, J., Martínez-Villaluenga, C., Peñas, E., Eds.; 2017; pp. 63-83. [CrossRef]

37. Zhang, Y.; Liu, W.; Wei, Z.; Yin, B.; Man, C.; Jiang, Y. Enhancement of functional characteristics of blueberry juice fermented by Lactobacillus plantarum. LWT 2021, 139, 110590. [CrossRef]

38. Esteban-Torres, M.; Landete, J.M.; Reveron, I.; Santamaria, L.; de Las Rivas, B.; Muñoz, R. A Lactobacillus plantarum esterase active on a broad range of phenolic esters. Appl. Environ. Microbiol. 2015, 81, 3235-3242. [CrossRef] [PubMed]

39. Mousavia, Z.E.; Mousavia, S.M.; Razavia, S.H.; Hadinejada, M.; Emam-Djomeha, Z.; Mirzapoura, M. Effect of Fermentation of Pomegranate Juice by Lactobacillus plantarum and Lactobacillus acidophilus on the Antioxidant Activity and Metabolism of Sugars, Organic Acids and Phenolic Compounds. Food Biotechnol. 2013, 27, 1-13. [CrossRef]

40. Zhu, Y.Q.; Zhang, A.; Tsang, D.; Huang, Y.; Chen, Z.Y. Stability of Green tea catechins. J. Agric. Food Chem. 1997, 45, 4624-4628. [CrossRef]

41. Yoshida, Y.; Kiso, M.; Goto, T. Effect of $\mathrm{pH}$ and tea concentration on extraction of catechins from Japanese green tea. ACS Symp. Ser. Am. Chem. Soc. 2000, 754, 347-354. [CrossRef]

42. Adebo, A.A.; Medina-Menza, I.G. Impact of fermentation on the phenolic compounds and antioxidant activity of whole cereal grains. A mini review. Molecules 2020, 25, 927. [CrossRef]

43. Truchado, P.; Larrosa, M.; García-Conesa, M.T.; Cerdá, B.; Vidal-Guevara, M.L.; Tomás-Barberán, F.A.; Espín, J.C. Strawberry processing does not affect the production and urinary excretion of urolithins, ellagic acid metabolites, in humans. J. Agric. Food Chem. 2012, 60, 5749-5754. [CrossRef]

44. Rodríguez, H.; Landete, J.M.; Curiel, J.A.; de las Rivas, B.; Mancheño, J.M.; Muñoz, R. Characterization of the p-coumaric acid decarboxylase from Lactobacillus plantarum CECT 748T. J. Agric. Food Chem. 2008, 56, 3068-3072. [CrossRef] [PubMed]

45. Curiel, J.A.; Pinto, D.; Marzani, B.; Filannino, P.; Farris, G.A.; Gobbetti, M.; Rizzello, C.G. Lactic acid fermentation as a tool to enhance the antioxidant properties of Myrtus communis berries. Microb. Cell Fact. 2015, 14, 67. [CrossRef]

46. Filannino, P.; Bai, Y.; Di Cagno, R.; Gobbetti, M.; Gänzle, M.G. Metabolism of phenolic compounds by Lactobacillus spp. during fermentation of cherry juice and broccoli puree. Food Microbiol. 2015, 46, 272-279. [CrossRef]

47. Moloto, M.R.; Phan, A.D.T.; Shai, J.L.; Sultanbawa, Y.; Sivakumar, D. Comparison of phenolic compounds, carotenoids, amino acid composition, in vitro antioxidant and anti-diabetic activities in the leaves of seven cowpea (Vigna unguiculata) cultivars. Foods 2020, 9, 1285. [CrossRef] [PubMed]

48. Muruganandan, S.; Srinivasan, K.; Gupta, S.; Gupta, P.K.; Lal, J. Effect of mangiferin on hyperglycemia and atherogenicity in streptozotocin diabetic rats. J. Ethnopharmacol. 2005, 97, 497-501. [CrossRef] [PubMed]

49. Mackie, A.; Mulet-Cabero, A.I.; Torcello-Gómez, A. Simulating human digestion: Developing our knowledge to create healthier and more sustainable foods. Food Funct. 2020, 11, 9397-9431. [CrossRef]

50. Rodriguez-Roque, M.J.; Rojas-Grauü, M.A.; Elez-Martinez, P.; Martin-Belloso, O. Changes in vitamin C, phenolic, and carotenoid profiles throughout in vitro gastrointestinal digestion of a blend fruit juice. J. Agric. Food Chem. 2013, 61, 1859-1867. [CrossRef]

51. Bouayed, J.; Hoffmann, L.; Bohn, T. Total phenolics, flavonoids, anthocyanins and antioxidant activity following simulated gastro-intestinal digestion and dialysis of apple varieties: Bioaccessibility and potential uptake. Food Chem. 2011, $28,14-21$. [CrossRef] [PubMed]

52. Tagliazucchi, D.; Verzelloni, E.; Bertolini, D.; Conte, A. In vitro bio-accessibility and antioxidant activity of grape polyphenols Food Chem. 2010, 120, 599-606. [CrossRef]

53. Jara-Palacios, M.J.; Gonçalves, S.; Hernanz, D.; Heredia, F.J. Effects of in vitro gastrointestinal digestion on phenolic compounds and antioxidant activity of different white winemaking by products extracts. Food Res. Int. 2018, 109, 433-439. [CrossRef] [PubMed]

54. Liu, B.; Li, W.; Hu, L.; Zhao, L. Mild alkaline hydrolysis is an efficient and low cost method for improving the free phenolic content and health benefit of pomegranate peel extract. J. Food Process Pres. 2013, 37, 694-700. [CrossRef] 
55. Neilson, A.P.; Hopf, A.S.; Cooper, B.R.; Pereira, M.A.; Bomser, J.A.; Ferruzzi, M.G. Catechin degradation with concurrent formation of homo- and heterocatechin dimers during in vitro digestion. J. Agric. Food Chem. 2007, 55, 8941-8949. [CrossRef] [PubMed]

56. Larrosa, M.; Garcia-Conesa, M.T.; Espin, J.C.; Tomas-Barberan, F.A. Ellagitannins, 524 ellagic acid and vascular health. Mol. Aspects Med. 2010, 31, 513-539. [CrossRef]

57. Zhaoping, L.; Summanen, P.H.; Komoriya, T.; Henning, S.M.; Lee, R.P.; Carlson, E.; Heber, D.; Finegold, S.M. Pomegranate ellagitannins stimulate growth of gut bacteria in vitro: Implications for prebiotic and metabolic effects. Anaerobe 2015, 34, 164-168. [CrossRef]

58. Hur, S.J.; Lee, S.; Kim, D.; Chun, S.; Lee, S. Onion extract structural changes during in vitro digestion and its potential antioxidant e_ect on brain lipids obtained from low-and high-fat-fed mice. Free Radic. Res. 2013, 47, 1009-1015. [CrossRef]

59. Degrain, A.; Manhivi, V.; Remize, V.; Remize, F.; Garcia, C.; Sivakumar, D. Effect of lactic acid fermentation on colour, phenolic compounds and antioxidant activity in African nightshade. Microorganisms 2020, 8, 1324. [CrossRef] [PubMed]

60. Mateo Anson, N.; Nordlund, E.; Havenaar, R.; Aura, A.-M.; Mattila, I.; Lehtinen, P.; Bast, A.; Poutanen, K.; Haenen, G. Bioprocessing of wheat bran improves in vitro bioaccessibility and colonic metabolism of phenolic compounds. J. Agric. Food Chem. 2009, 57, 6148-6155. [CrossRef] [PubMed] 